\title{
Liquid Biopsies beyond Mutation Calling: Genomic and Epigenomic Features of Cell-Free DNA in Cancer
}

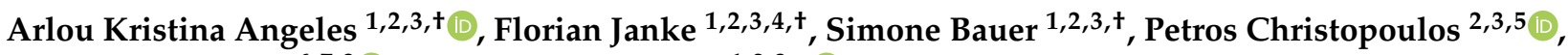 \\ Anja Lisa Riediger $6,7,8(1)$ and Holger Sültmann $1,2,3, * \mathbb{C}$
}

1 Division of Cancer Genome Research, German Cancer Research Center (DKFZ) and German Cancer Consortium (DKTK), 69120 Heidelberg, Germany; a.angeles@dkfz.de (A.K.A.); f.janke@dkfz.de (F.J.); mone-bauer@gmx.de (S.B.)

2 National Center for Tumor Diseases (NCT), 69120 Heidelberg, Germany; petros.christopoulos@med.uni-heidelberg.de

3 Translational Lung Research Center, German Center for Lung Research (DZL) at Heidelberg University Hospital, 69120 Heidelberg, Germany

4 Medical Faculty, Heidelberg University, 69120 Heidelberg, Germany

5 Department of Oncology, Thoraxklinik at Heidelberg University Hospital, 69126 Heidelberg, Germany

6 Helmholtz Young Investigator Group, Multiparametric Methods for Early Detection of Prostate Cancer, German Cancer Research Center (DKFZ), 69120 Heidelberg, Germany; anjalisa.riediger@med.uni-heidelberg.de

7 Department of Urology, Heidelberg University Hospital, 69120 Heidelberg, Germany

8 Faculty of Biosciences, Heidelberg University, 69120 Heidelberg, Germany

* Correspondence: h.sueltmann@dkfz.de; Tel.: +49-6221-56-5934

+ These authors contributed equally to this work.

Citation: Angeles, A.K.; Janke, F.; Bauer, S.; Christopoulos, P.;

Riediger, A.L.; Sültmann, H. Liquid Biopsies beyond Mutation Calling: Genomic and Epigenomic Features of Cell-Free DNA in Cancer. Cancers 2021, 13, 5615. https://doi.org/ $10.3390 /$ cancers 13225615

Academic Editor: Galatea Kallergi

Received: 13 October 2021

Accepted: 9 November 2021

Published: 10 November 2021

Publisher's Note: MDPI stays neutral with regard to jurisdictional claims in published maps and institutional affiliations.
Simple Summary: Liquid biopsies provide a non-invasive means to diagnose and profile tumors when tissue is not available. Sequence-based analysis of cell-free DNA (cfDNA) is frequently used to characterize genomic alterations, with a focus on driver mutations or mechanisms of acquired therapy resistance. However, the epigenome of cfDNA also contains additional information about the tumor, which might open new possibilities for clinical applications. Recent highlighted publications are reviewed on the analysis of fragmentation, epigenomic alterations, as well as nucleosome modifications using cfDNA in various cancers. The potential, challenges, and future directions of genomic and epigenomic analysis of cfDNA in oncology are discussed.

Abstract: Cell-free DNA (cfDNA) analysis using liquid biopsies is a non-invasive method to gain insights into the biology, therapy response, mechanisms of acquired resistance and therapy escape of various tumors. While it is well established that individual cancer treatment options can be adjusted by panel next-generation sequencing (NGS)-based evaluation of driver mutations in cfDNA, emerging research additionally explores the value of deep characterization of tumor cfDNA genomics and fragmentomics as well as nucleosome modifications (chromatin structure), and methylation patterns (epigenomics) for comprehensive and multi-modal assessment of cfDNA. These tools have the potential to improve disease monitoring, increase the sensitivity of minimal residual disease identification, and detection of cancers at earlier stages. Recent progress in emerging technologies of cfDNA analysis is summarized, the added potential clinical value is highlighted, strengths and limitations are identified and compared with conventional targeted NGS analysis, and current challenges and future directions are discussed.

Keywords: liquid biopsy; cell-free DNA; precision medicine; fragmentomics; epigenomics; DNA methylation; DNA hydroxymethylation; histone modification; nucleosome positioning

\section{Introduction}

The development of advanced genomic technologies has caused an upsurge in methods of cell-free DNA (cfDNA) analysis during the past decade. The potential clinical utility 
of these novel techniques is huge, ranging from the non-invasive monitoring of infections, to the early diagnosis of graft rejection after solid organ transplantation [1-3], detection of fetal aneuploidy in pregnant women [4,5], and a wide array of applications in oncology. The main benefits of cfDNA over tissue analysis for cancer patients are a higher sampling frequency with reduced procedural risk, as well as the ability of each sample to reflect all tumor lesions in the body, thus overcoming the obstacles posed by temporal [6] and spatial [7] tumor heterogeneity. Thus, cfDNA can be used to explore the evolutionary dynamics of cancers across the entire genomic spectrum. Accordingly, circulating tumor DNA (ctDNA) can be used to diagnose and profile tumors at initial diagnosis, monitor disease progression, characterize mechanisms of acquired resistance, identify minimal residual disease (MRD), and discover potential novel therapeutic targets.

cfDNA sources vary in certain physiological or disease contexts. In healthy individuals, the main sources of cfDNA are lymphoid and myeloid cells, consistent with the frequent turnover of hematopoietic lineage cells in the blood [8]. In cancer, the detection and quantification of mutations, $\mathrm{CNVs}$, and aneuploidies from tumor-derived cfDNA have been successfully used to monitor advanced disease and treatment response [9-11]. CfDNA concentrations were shown to be elevated in cancer patients (even at localized disease) compared with healthy individuals [12,13]. Multiple studies have also reported the potential of ctDNA analysis in oligoprogression [14] as well as in early detection of disease progression (i.e., lead time), in which detection of tumor mutational clones precedes conventional imaging modalities [15-18]. However, determining the source of cfDNA (i.e., tumor vs. healthy tissue) remains a prevailing limitation in genomic analyses of cfDNA. Another limitation is that-while it is possible to track tumor progression based on cfDNA single nucleotide variations (SNVs) and copy number variations (CNVs) — definitive identification of a tumor's tissue-of-origin based on these parameters is not always possible.

Beyond the conventional cfDNA analysis using targeted NGS (tNGS) [19,20], epigenomic changes in tumor tissues also vary during tumor initiation and progression [21]. In addition, DNA methylation and chromatin modifications or transcription factor binding sites have been described to be highly tissue specific [22-26], and could be used to resolve the tissue-of-origin in early cancer detection [27-29]. For example, SEPT9 promoter methylation is a biomarker for the early detection of lung adenocarcinoma and colorectal cancer (CRC) [30,31]. cfDNA fragments also harbor information about the nucleosome occupancy in tissues, which might inform about their cell-of-origin [8]. Still, a major challenge hindering translation into clinical applications is the low abundance of analytes derived from certain tumor types, such as prostate [32], glioblastoma [33], and renal cancers [34], especially in early tumor stages [35].

\section{Fragmentation Patterns of cfDNA}

For many years, it has been known that the size distribution of cfDNA is not random and might contain information about the mechanisms of its release [36]. The cfDNA size peak of $\sim 167 \mathrm{bp}$ reflects the length of the DNA strand wrapped around nucleosomes (147 bp) plus linker DNA fragments of $20 \mathrm{bp}$. This pattern is generated via caspasedependent DNA cleavage, which implies that a large fraction of cfDNA is released from cells undergoing apoptosis. However, recent studies suggesting that cfDNA fragmentation depends on certain pathological conditions, such as cancer [37-41], have fueled research on the identification of additional fragmentation mechanisms (Table 1).

\subsection{Shortening of cfDNA Fragments in Cancer}

Jiang et al. [42] demonstrated that the cfDNA fragment length profile in patients suffering from hepatocellular carcinoma (HCC) was shifted towards lower sizes compared with healthy individuals (145 bp). They estimated the fractions of ctDNA based on the prevalence of copy number alterations (chromosome arm-level z-score analysis). Samples with high fractions of ctDNA showed increased proportions of fragments $<150 \mathrm{bp}$, whereas ctDNA content and fragments between 150 and $180 \mathrm{bp}$ were not correlated. When analyz- 
ing fragment size distributions of different tumor entities, Mouliere et al. made similar observations, showing that tumors known to shed high amounts of ctDNA (e.g., lung or colorectal cancer) into the bloodstream also presented increased proportions of fragments $<150$ bp, compared with low ctDNA cancers (e.g., renal cancer, glioblastoma) and to cfDNA from healthy donors [41]. cfDNA shortening was also observed during pregnancy, where DNA derived from the fetus is ca. 20 bp shorter than maternal cfDNA $[43,44]$, and between donor and host cfDNA in organ transplant recipients [45].

The biological and physical processes responsible for cfDNA shortening are not fully understood. Epigenomic processes might play a role, since hypomethylated cfDNA fragments tend to be shorter than hypermethylated DNA [46,47]. Considering that DNA methylation influences nucleosomal packaging [48], hypomethylated cfDNA might be less densely associated with nucleosomes and therefore more susceptible to nucleases.

Several studies have investigated the shortening of cfDNA for improved tumor detection [37,38,41,49]. For example, Mouliere et al. [41] achieved up to 11-fold ctDNA enrichment by analyzing cfDNA fragments between 90 and 150 bp only. Consequently, they were able to improve the detection of copy number variations (CNV) and single nucleotide variations (SNV). Further studies corroborated the enhanced sensitivity of CNV and SNV detection after selecting short cfDNA fragments using either in vitro or in silico enrichment methods [34,38,41,50,51]. Cristiano et al. [37] applied a different approach in which the length variations of ctDNA were considered in a position-specific manner using shallow whole genome sequencing (sWGS). They compared the fractions of small (100 to $150 \mathrm{bp}$ ) to large (151 to $220 \mathrm{bp}$ ) cfDNA fragments within $5 \mathrm{Mb}$ bins throughout the genome in samples from 236 healthy donors and 245 patients suffering from various cancers. cfDNA fragments of healthy individuals were highly concordant with and reflected the fragmentation of lymphocytic nucleosomal DNA. The cfDNA fragmentation from patients was much more variable and exhibited regional increases in particular fragment lengths. In a subset of these samples, the degree of fragmentation alterations was correlated to the SNV fractions. This suggested that position-specific alterations of cfDNA size profiles could be used for cancer detection. Using machine learning (ML) on the cfDNA fragmentation profile data, cancer patients could be identified with a sensitivity of $73 \%$ and a specificity of $98 \%$. The tissue-of-origin was correctly classified in $61 \%$ of cases [37]. Smith et al. applied a random forest algorithm for ctDNA detection based on cfDNA fragmentation features obtained from sWGS of plasma and urine DNA in renal cell carcinoma (RCC) patients [34] and obtained $91.7 \%$ prediction accuracy. This result indicates that sWGS is an inexpensive approach which can identify samples for targeted NGS analyses to detect potentially actionable gene-specific alterations (Figure 1).

While double-stranded DNA (dsDNA) library preparation is insensitive to highly degraded cfDNA, single-stranded (ssDNA) libraries can capture such molecules and might provide a better insight into shorter-sized DNA molecules: using ssDNA library preparation and quantitative PCR, a cfDNA population with a significantly shorter fragment length profile (30 to $130 \mathrm{bp}$ ) was identified compared with the standard dsDNA method [8,52-54]. These data also revealed that circulating DNA does not only associate with nucleosomes but also tends to be occupied by transcription factors (TFs) with size ranges between 20 and $90 \mathrm{bp}$ [54]. In addition, ssDNA sequencing data showed that nucleosome-associated cfDNA presents high numbers of ssDNA breaks that are missed in the preparation of conventional dsDNA libraries. These single-stranded nicks were found to be more frequent in samples of cancer patients compared with healthy individuals, indicating higher nuclease activity in patients $[53,54]$. The recovery of very short DNA molecules might also improve the detection of mitochondrial cfDNA that revealed promising results in the differentiation between HCC patients and healthy donors [42], or of recipient vs. donor cfDNA after lung transplantation [52]. In contrast, fragments $>250$ bp present only a minor fraction of the cfDNA repertoire and have received little attention so far. However, one study observed that mutated cfDNA was also enriched for fragments between 250 and 320 bp compared with non-mutated cfDNA fragments [41]. 


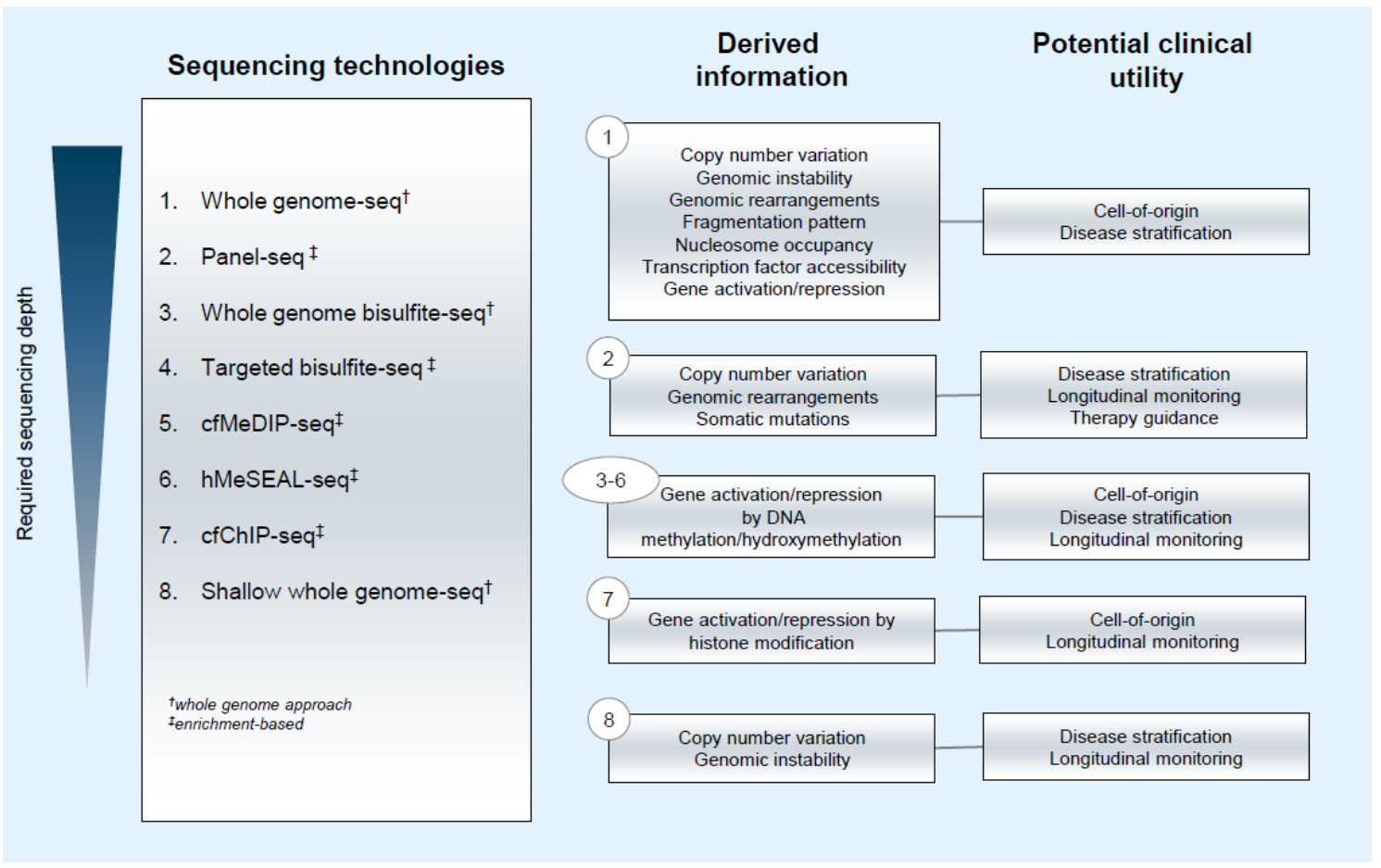

Figure 1. Information output and potential clinical utility of sequencing technologies applied for ctDNA analysis.

\subsection{Cancer-Associated Alterations of cfDNA Fragment End Sequences}

The ends of cfDNA fragments provide insights into the biology of cfDNA fragmentation and were also shown to have potential clinical implications in cancer patients. Such informative characteristics include the genomic location of the fragment ends [55,56], their sequence context at the $5^{\prime}$-end [39,57-59], and single-stranded $5^{\prime}$ protruding ("jagged") ends $[60,61]$. Whole genome sequencing (WGS) of cfDNA from pregnant women has shown that cfDNA fragment ends are not equally distributed in the genome [55]. These "plasma DNA preferred ends" were linked to genomic regions with open chromatin, emphasizing that cfDNA is preferentially cleaved at accessible sites of the genome [62]. Since chromatin accessibility differs between cell and tissue types [8,63], the fragment ends of maternal and fetal cfDNA vary considerably and are characteristic for their tissues-of-origin, i.e., hematopoietic cells $[42,64,65]$ vs. placental trophoblasts, respectively [55].

Similar observations were made in HCC patients. Jiang et al. [56] identified cfDNA fragment end coordinates specific for HCC and validated their tumor association in a cohort of 90 HCC patients, 32 healthy donors, 67 chronic hepatitis B virus (HBV) carriers, and 36 patients suffering from liver cirrhosis. Enrichment of tumor-associated jagged ends in cfDNA was only found in HCC patients, further corroborating the concept of tissue- or tumor-specificity of cfDNA ends. Moreover, tumor-derived fragment ends were shorter and correlated to the ctDNA fraction in the same plasma samples.

Chandrananda et al. [57] were the first to show that not only the location but also the sequence context of cfDNA is associated with distinct biological processes. They reported an increased abundance of cytosines at the $5^{\prime}$-ends of cfDNA molecules, which was absent from randomly sheared cellular DNA and mitochondrial cfDNA. This suggests that the $5^{\prime}$-sequence preference is associated with DNA cleavage between nucleosomes. Similar C-end dominance was detected in murine cfDNA samples [58]. The overrepresentation of certain fragment end motifs was linked to the cutting preference of different nucleases, particularly of deoxyribonuclease 1-like 3 (DNASE1L3) [58,59]. DNASE1L3 and DNASE1 are the most abundant DNases in mammalian plasma [66]. While DNASE1L3 cuts chromatinassociated DNA at nucleosomal linker regions, DNASE1-mediated cleavage predominantly occurs at protein-free DNA molecules, generating A-end fragments [40,59]. The expression 
levels of DNASE1L3 are significantly reduced in several cancer entities, including breast, lung, colorectal and liver cancer [67]. A study on plasma samples from 34 HCC patients demonstrated that the low expression of DNASE1L3 in HCC coincides with a reduction of many of the DNASE1L3-associated motifs (e.g., CCCA, CCAG, and CCTG), and an increase in other motifs in these patients (e.g., TAAA, AAAA, and TTTT) [67]. A global increase in the end motif diversity was also observed in the cfDNA from cancer patients, which might be due to the reduced expression of DNASE1L3, resulting in altered cfDNA end motif compositions. Elevated end motif diversities were observed in different cancer entities with reduced DNASE1L3 expression levels (e.g., colorectal and lung cancer) [67].

Table 1. Fragmentomic features of cfDNA in cancer.

\begin{tabular}{|c|c|c|c|c|c|c|}
\hline $\begin{array}{l}\text { cfDNA Fragment } \\
\text { Feature }\end{array}$ & Method & Analyte & Control Cohort & $\begin{array}{c}\text { Cancer Entity } \\
\text { Tested }\end{array}$ & Result & Reference \\
\hline $\begin{array}{l}\text { Fragment length } \\
\text { shortening }\end{array}$ & WGS & Plasma & $\begin{array}{l}\text { Healthy controls }(n=32), \text { HBV } \\
(n=67), \text { liver cirrhosis }(n=36)\end{array}$ & $\operatorname{HCC~}(n=90)$ & $\begin{array}{l}\text { Short cfDNA fragments } \\
\text { preferentially carry } \\
\text { tumor-associated CNVs }\end{array}$ & [42] \\
\hline $\begin{array}{l}\text { Fragment length } \\
\text { shortening }\end{array}$ & sWGS & CSF & $\mathrm{n} / \mathrm{a}$ & Glioma $(n=13)$ & $\begin{array}{c}\text { Detectable CNVs in CSF } \\
\text { correlates with higher } \\
\text { abundance of short }(<145 \mathrm{bp}) \\
\text { cfDNA fragments }\end{array}$ & [51] \\
\hline $\begin{array}{l}\text { Fragment length } \\
\text { shortening }\end{array}$ & $\begin{array}{l}\text { tNGS; } \\
\text { ddPCR }\end{array}$ & Plasma & $\mathrm{n} / \mathrm{a}$ & $\begin{array}{l}\text { Melanoma }(n=8), \\
\text { CRC }(n=3), \text { and } \\
\text { pancreatic }(n=2) \\
\text { cancer }\end{array}$ & $\begin{array}{l}\text { 2-fold enrichment of SNVs in } \\
\text { short }(<142 \text { bp) cfDNA } \\
\text { fragments }\end{array}$ & [38] \\
\hline $\begin{array}{l}\text { Fragment length } \\
\text { shortening }\end{array}$ & $\begin{array}{l}\text { sWGS; } \\
\text { tNGS }\end{array}$ & Plasma & $\mathrm{n} / \mathrm{a}$ & $\begin{array}{l}\text { High-grade serous } \\
\text { ovarian cancer } \\
\quad(n=13)\end{array}$ & $\begin{array}{l}\text { Up to } 11 \text {-fold enrichment of the } \\
\text { mutated cfDNA fraction in } \\
\text { short fragments ( } 90 \text { to } 150 \mathrm{bp} \text { ) }\end{array}$ & [49] \\
\hline $\begin{array}{l}\text { Multiple fragment } \\
\text { size features }\end{array}$ & $\begin{array}{l}\text { sWGS; } \\
\text { tNGS }\end{array}$ & Plasma & Healthy controls $(n=144)$ & $\begin{array}{l}\text { Multiple } \\
\text { cancerentities } \\
(n=200)\end{array}$ & $\begin{array}{c}\text { Enhanced CNV/SNV detection } \\
\text { by short fragments; } \\
\text { fragmentation feature-based } \\
\text { cancer classification } \\
(\text { AUC }=0.99)\end{array}$ & [41] \\
\hline $\begin{array}{l}\text { Position-specific } \\
\text { fragment length } \\
\text { variations }\end{array}$ & WGS & Plasma & Healthy controls $(n=245)$ & $\begin{array}{l}\text { Multiple cancer } \\
\text { entities }(n=236)\end{array}$ & $\begin{array}{c}\text { Cancer detection based on } \\
\text { genome-wide cfDNA } \\
\text { fragmentation profiles } \\
(\mathrm{AUC}=0.94)\end{array}$ & [37] \\
\hline $\begin{array}{c}\text { Preferred end } \\
\text { coordinates }\end{array}$ & WGS & Plasma & $\begin{array}{l}\text { Healthy controls }(n=32), \text { HBV } \\
(n=67) \text {, liver cirrhosis }(n=36)\end{array}$ & $\operatorname{HCC}(n=90)$ & $\begin{array}{l}\text { Cancer classification based on } \\
\text { fragments at tumor-associated } \\
\text { preferred end coordinates } \\
\text { (AUC }=0.88)\end{array}$ & [56] \\
\hline $\begin{array}{l}\text { Fragment end } \\
\text { motifs }\end{array}$ & WGS & Plasma & $\begin{array}{l}\text { Healthy controls }(n=38), \mathrm{HBV} \\
\qquad(n=17)\end{array}$ & $\operatorname{HCC}(n=34)$ & $\begin{array}{l}\text { Increased fragment end motif } \\
\text { diversity in patients compared } \\
\text { with controls }\end{array}$ & {$[67]$} \\
\hline Jagged ends & WGBS & Plasma & $\begin{array}{l}\text { Healthy controls }(n=8), \mathrm{HBV} \\
\qquad(n=17)\end{array}$ & $\operatorname{HCC}(n=34)$ & $\begin{array}{c}\text { Cancer classification based on } \\
\text { the increased jaggedness in } \\
\text { cancer patients }\end{array}$ & [60] \\
\hline Jagged ends & WGBS & Urine & Healthy controls $(n=39)$ & $\begin{array}{l}\text { Bladder cancer } \\
\quad(n=43)\end{array}$ & $\begin{array}{c}\text { Cancer classification based on } \\
\text { the decreased jaggedness in } \\
\text { cancer patients }\end{array}$ & {$[61]$} \\
\hline
\end{tabular}

AUC, area under the curve; CNV, copy number variation; CRC, colorectal cancer; CSF, cerebrospinal fluid; ddPCR, digital droplet PCR; HBV, hepatitis B virus; HCC, hepatocellular carcinoma; sWGS, shallow whole genome sequencing; tNGS, targeted next-generation sequencing; WGB, whole genome bisulfite sequencing; WGS, whole genome sequencing.

More recently, cfDNA molecules were found to possess single-stranded 5' DNA overhangs $[60,61]$. The presence of these jagged ends is normally masked by the end repair step during conventional sequencing library preparation. To identify jagged ends, overhangs are extended using nucleotides with detectable characteristics. For example, methylated cytosines can be introduced during overhang elongation, and high abundance of methylated $\mathrm{CH}$ sites ( $\mathrm{H}: \mathrm{A}, \mathrm{T}$, or $\mathrm{C}$ ) at DNA fragment ends reflects the "jaggedness" of the original DNA molecules. Analysis of plasma DNA in DNASE1-deficient mice showed a decreased abundance of jagged ends compared with wild-type mice, suggesting that the jaggedness of cfDNA is related to DNASE1 activity [60]. The expression level of DNASE1 is elevated in HCC tumors compared with normal liver tissue, and cfDNA in HCC patients is more prone to have jagged ends compared with plasma from healthy donors [60]. Fragment end analysis of urinary cfDNA from bladder cancer patients revealed that stage-dependent reduction of DNASE1 expression coincided with reduced jaggedness of cfDNA compared with controls [61]. 
The possibility of inferring the tissue-of-origin from cfDNA fragmentation profiles provides a new layer of information that was previously missed. The correlation of the expression levels of nucleases to the abundance of fragment end motifs and jagged end fragments could guide the selection of cfDNA biomarkers in the future.

\section{Nucleosome Positioning and Chromatin Modifications in cfDNA}

\subsection{Deducing Gene Expression from Nucleosome Positioning and Occupancy}

One strategy to identify the cfDNA tissue-of-origin takes advantage of unique nucleosome positioning patterns in different cell types $[68,69]$. Snyder et al. [8] performed deep sequencing of cfDNA from healthy donors and applied a heuristic approach to generate genome-wide nucleosome occupancy based on the "windowed protection score" (WPS) metric (Table 2). Regions protected from digestion (e.g., by nucleosomes) yield high WPS values, while unprotected DNA regions are marked by low WPS scores. Further analysis of peak-to-peak spacing of nucleosome calls revealed that, in healthy samples, the high proportion of widened nucleosome spacing ( $260 \mathrm{bp})$ is comparable to observations made in cells of lymphoid or myeloid origin. This finding corroborated the notion that hematopoietic cell death is the prevalent source of cfDNA in healthy individuals. Further, the study utilized nucleosome spacing across gene bodies to infer gene expression levels from cfDNA. Open chromatin and active transcription correlated with tighter spacing between nucleosomes. By using nucleosome spacing within gene bodies as a surrogate for gene expression, it was possible to identify cell type specific signatures from deep cfDNA sequencing. The utility of this approach was illustrated by establishing correlations between nucleosome signatures from cfDNA of cancer patients (i.e., small cell or squamous cell lung cancer, colorectal adenocarcinoma, hepatocellular carcinoma, and ductal carcinoma in situ breast cancer) and gene expression signatures of cancer models (i.e., human cell lines and primary tissues) with the same tissues-of-origin. The method succeeded in matching three out of five test cases. While the study revealed the potential of using nucleosome tracks for predicting the cellular origin of tumors, it was limited by the low number of plasma samples tested, which were themselves biased towards harboring high aneuploidy metric scores (all were from stage IV patients).

Building on the insights presented by the previous study, Ulz et al. [63] explored the potential of using nucleosome occupancy at promoters based on WGS of cfDNA, to infer gene expression signatures associated with various cell types. This hypothesis relied on the premise that in actively transcribed genes, the promoter region including sequences of 1 kilobase (kb) downstream of the transcription start site (TSS), is a nucleosome-depleted region (NDR), which allows docking of the transcription initiation machinery. Flanking the NDR are uniformly positioned nucleosomes. Since the DNA at NDRs is not protected once shed into the circulation, sequence coverage of this region is poor. Hence, the read depth at the TSS of active genes is low, with distinct oscillations around the NDR. This is in contrast to higher read depths expected at the TSSs of inactive genes where nucleosome array packaging is denser. Upon comparison of read depth of cfDNA from healthy individuals with publicly available micrococcal nuclease assay datasets, a high concordance $(>90 \%)$ of cfDNA fragments was found to be derived from white blood cells, validating the utility of this method. Accordingly, Ulz et al. established a metric for gene expression based on read depth coverage of the $2-\mathrm{kb}$ region centered at the TSS and within the NDR defined from $-150 \mathrm{bp}$ to $+50 \mathrm{bp}$ with respect to the TSS. Read depths of these regions were normalized against relative copy numbers to account for the contribution of copy number changes to absolute read counts. This approach was successful in inferring the 100 most highly and least expressed genes in plasma with an accuracy of $91 \%$. To test the feasibility of the method in clinical samples, the study performed WGS on matched primary tumor and plasma DNA, as well as tumor RNA-seq from two patients with metastasized breast cancer. Integrating these data, it was possible to identify copy number variations (CNVs) to estimate the ctDNA fraction and facilitate accurate predictions of gene expression from promoter read depths. This analysis was limited to regions with high ctDNA allele fre- 
quencies, revealing practical caveats of the method, particularly its low prediction accuracy for samples with low tumor load and hence unsuitability in MRD monitoring, as well as in assessing cfDNA from patients with tumors known to shed minimal ctDNA. Nonetheless, the robustness of the method was tested in cfDNA from patients with metastasized cancer of various origins (i.e., colon, prostate, breast, lung; $n=426$ ), and $51.6 \%$ of the samples were amenable for promoter read depth analysis. Despite the limitations, using NDR quantification at promoter regions expands the repertoire of analyses that can be performed on cfDNA, while also enabling deduction of gene expression from WGS data of cfDNA. A commentary [70] proposed an improvement of the method, which requires deeper sequencing of cfDNA to identify and enrich for specific regions pertinent to the disease context. This way, the sequencing costs can be mitigated while the most informative genomic regions are sufficiently covered.

The work on cfDNA fragmentation patterns was further expanded by Sun et al. upon their development of a novel approach of utilizing tissue-specific open chromatin regions to infer the tissue-of-origin [71]. The method takes cfDNA orientation into consideration and differentiates the upstream (U) and downstream (D) ends of the DNA fragment based on their alignment to the reference genome. The group reproduced the nucleosomal periodicity of $\sim 190 \mathrm{bp}$ as reflected by the depth of coverage at nucleosomes and linkers. Depending on the phasing of the fragment end peaks, it was possible to deduce regions of open chromatin. This was based on the previous observation that open chromatin regions harbor regulatory elements in the absence of nucleosomes which are flanked by well-phased nucleosome arrays. The group developed a metric termed "orientation-aware cfDNA fragmentation" (OCF) value, which measures the differential phasing of U and D fragment ends. Due to the specific chromatin landscapes in different tissue types, distinct ranges of OCF values were accordingly observed in various tissue controls. Finally, OCF analysis was applied to noninvasive prenatal testing, patients with liver pathologies such as liver transplantation and hepatocellular carcinoma, colorectal cancer, and lung cancer patients. This cfDNA assay does not require high sequencing depths (median depth: $3.2 \times$ ), which differentiates it from the other nucleosomal positioning approaches described above.

\subsection{Inference of Transcription Factor Binding}

In addition to establishing a method to map nucleosome positions from cfDNA sequences, Snyder et al. [8] also deduced the occurrence of TF binding using shorter cfDNA fragments associated with cleavage next to transcription factor binding sites (TFBS), as opposed to longer cfDNA fragments associated with cleavage between nucleosomes. Extending this work, Ulz et al. [72] generated a metric which measures the accessibility of TFBS from cfDNA nucleosome coverage patterns. On initial analysis, read depths at TFBS inform of TF binding, indicative of TF activity specific to certain cell lineages. Accessibility scores were generated for 504 TFs, each with 1000 well-characterized TFBSs. Detection thresholds for TFBS accessibility differences from normal samples were defined, and the measured deviations of accessibility scores were used to validate signature TF activities in prostate, breast, and colon cancer-derived cfDNA. The study also presented three potential clinical applications of TF analysis. First, in a prostate cancer case which transdifferentiated to a treatment-emergent small cell neuroendocrine (t-SCNC) subtype, two plasma samples collected in a 12-month interval showed decreased accessibility of AR binding sites, reflecting the androgen-independent pathology of t-SCNC. Reduced accessibilities were also observed for HOXB13, NKX3-1, and REST. These observations suggest the possibility of cfDNA TF analysis for molecular tumor subtyping. Second, plasma samples from early-stage colon adenocarcinoma patients (COAD stage I, $n=197$; stage II, $n=280)$, and from individuals with no cancer diagnosis $(n=177)$ were compared, to assess the resolution limits of TF-based cancer detection. In stage I and II COAD cancers, tumors are still localized and consequently, the tumor fractions from cfDNA for most samples measured less than the detection limit of an established algorithm. However, statistically significant changes in binding by colon cancer-associated TFs were already 
apparent for early-stage patients compared with healthy controls. Further, upon model training by logistic regression analysis on 504 TFs, using a subset of early-stage COAD samples, the method was able to correctly identify stage I and II patients with precisions of $74 \%$ and $84 \%$, respectively. These results highlight the utility of the approach to establish classifiers for predicting early-stage cancers, which is currently a fundamental weakness of cfDNA technologies. Finally, nucleosome positioning studies typically require deep WGS of cfDNA. Notably, Snyder et al. [8] utilized 1.5 billion reads per sample to perform TF footprinting, which would translate to exorbitant clinical costs. In contrast, the current method [72] can perform reliable TF analysis even when sequencing is downsampled to 50 million reads (Figure 1).

\subsection{Histone Modification of cfDNA Nucleosomes as a Measure of Transcriptional Activity}

Sadeh et al. [29] developed a chromatin immunoprecipitation (ChIP) method applicable to cell-free nucleosomes in plasma, followed by sequencing (cfChIP-seq), taking advantage of intact histone marks to define gene expression signatures present in plasma DNA and trace their tissues-of-origin (Table 2). In this study, cfChIP-seq was performed in $<2 \mathrm{~mL}$ of plasma using antibodies targeting marks of active promoters (H3K4me3 or $\mathrm{H} 3 \mathrm{~K} 4 \mathrm{me} 2)$, enhancers (H3K4me2 or H3K4me1), and gene bodies of actively transcribed genes (H3K36me3). Accordingly, H3K4me3 pulldown of cfDNA from healthy individuals yielded considerably overlapping occupancies with reference H3K4me3 ChIP-seq maps of monocytes and neutrophils, verifying the main contributors of cell-free nucleosomes in healthy plasma. Moreover, cfDNA H3K4me3 enrichment at promoters was consistent with the expression levels of genes in hematopoietic cells based on reference tissue expression data. To test whether cfChIP-seq could predict gene expression changes in patients with underlying pathological conditions, $\mathrm{H} 3 \mathrm{~K} 4 \mathrm{me} 3$ precipitation was performed on plasma from healthy donors, from patients diagnosed with metastatic CRC, and patients with autoimmune, metabolic, or viral liver disease or with acute myocardial infarction. Using published ChIP-seq data, the authors generated cell type-specific gene expression signatures to be used as references. cfChIP-seq was able to reflect the tissue-of-origin of the most relevant cfDNA contributors in each of these pathologies, based on H3K4me3inferred transcriptional program activation. The study also challenged the abundance of erythroblast-derived cfDNA in plasma from healthy donors, as previously reported [64,73]. Instead, the authors observed enrichment for megakaryocyte-specific genes, implying that megakaryocytes are major contributors of cfDNA in healthy individuals. For the metastatic CRC cohort, a highly discriminative CRC classifier was generated based on COAD genes from the TCGA dataset (area under the ROC curve [AUC]: 0.94). Furthermore, the CRC signature scores derived from longitudinal cfChIP-seq data showed changes reflecting the disease status of patients at particular points of the therapy lines. The study also explored inter-tumor heterogeneity through cfChIP-seq-derived expression signatures. Five signatures were generated that could stratify metastatic CRC based on gene expression programs and duplication events. However, it remained unclear if these signatures would correlate with the genotypic background of the CRC tumors. Overall, Sadeh et al. developed a nuanced approach for cfChIP-seq analysis that should be extended to larger cohort numbers and perhaps other tumor entities. 
Table 2. Histone modifications and nucleosomal positioning in cfDNA from plasma.

\begin{tabular}{|c|c|c|c|c|c|}
\hline $\begin{array}{l}\text { Cf Nucleosome } \\
\text { Feature }\end{array}$ & Method & $\begin{array}{l}\text { Control Cohort Used } \\
\text { for Method } \\
\text { Establishment } \\
\end{array}$ & Cancer Entity Tested & Result & Reference \\
\hline $\begin{array}{l}\text { Nucleosome } \\
\text { positioning }\end{array}$ & $\begin{array}{c}\text { Evaluation of } \\
\text { windowed protection } \\
\text { score (WPS) using deep } \\
\text { WGS }\end{array}$ & $\begin{array}{l}\text { Pooled }(n=1) \text { and } \\
\text { individual cfDNA }(n= \\
\text { 2) from healthy controls }\end{array}$ & $\begin{array}{l}\text { Small and squamous cell lung } \\
\text { cancer, colorectal } \\
\text { adenocarcinoma, hepatocellular } \\
\text { carcinoma, ductal carcinoma in } \\
\text { situ breast cancer }\end{array}$ & $\begin{array}{l}\text { Matched } 3 \text { out of } 5 \text { cancer test } \\
\text { samples to a reference } \\
\text { cell-of-origin model }\end{array}$ & [8] \\
\hline $\begin{array}{l}\text { Nucleosome } \\
\text { depleted regions }\end{array}$ & $\begin{array}{l}\text { Analysis of promoter } \\
\text { read depth using deep } \\
\text { WGS }\end{array}$ & $\begin{array}{l}\text { cfDNA from healthy } \\
\text { controls } \\
(n=104)\end{array}$ & $\begin{array}{c}\text { Colon }(n=128), \text { prostate } \\
(n=139), \text { breast }(n=125), \text { lung } \\
(n=31) \text { cancers }\end{array}$ & $\begin{array}{l}\text { Identified expressed cancer } \\
\text { driver genes from cfDNA in } \\
\text { regions with copy number gains }\end{array}$ & [63] \\
\hline $\begin{array}{l}\text { Nucleosome } \\
\text { phasing }\end{array}$ & $\begin{array}{l}\text { Analysis of differential } \\
\text { phasing of upstream } \\
\text { and downstream } \\
\text { cfDNA fragments using } \\
\text { WGS }\end{array}$ & $\begin{array}{l}\text { Pooled cfDNA } \\
(n=32) \text { from healthy } \\
\text { controls }\end{array}$ & $\begin{array}{c}\text { Hepatocellular carcinoma } \\
(n=90), \text { colorectal }(n=11), \text { and } \\
\text { lung }(n=9) \text { cancers }\end{array}$ & $\begin{array}{l}\text { Positive correlation of } \\
\text { nucleosome phasing between } \\
\text { cell-of-origin and patient cfDNA }\end{array}$ & [71] \\
\hline $\begin{array}{l}\text { Nucleosome } \\
\text { footprinting }\end{array}$ & $\begin{array}{c}\text { Assessment of } \\
\text { transcription factor } \\
\text { accessibility score using } \\
\text { WGS }\end{array}$ & $\begin{array}{l}\text { cfDNA from healthy } \\
\text { controls }(n=24)\end{array}$ & $\begin{array}{l}\text { Prostate }(n=8), \text { breast }(n=2), \\
\quad \text { colon }(n=1) \text { cancers }\end{array}$ & $\begin{array}{c}\text { Identified cell lineage } \\
\text { reprogramming in prostate } \\
\text { cancer; identified increased } \\
\text { accessibility by tumor entity } \\
\text { specific TFs in breast and colon } \\
\text { cancer samples }\end{array}$ & [72] \\
\hline $\begin{array}{l}\text { Histone } \\
\text { modifications }\end{array}$ & cfDNA ChIP-seq & $\begin{array}{l}\text { cfDNA from healthy } \\
\text { controls } \\
(n=61)\end{array}$ & $\begin{array}{l}\text { Metastatic colorectal cancer } \\
\qquad(n=56)\end{array}$ & $\begin{array}{l}\text { Colorectal cancer classifier was } \\
\text { established based on histone } \\
\text { modification occupancy-inferred } \\
\text { expression; longitudinal } \\
\text { monitoring reflected the clinical } \\
\text { status of patients }\end{array}$ & [29] \\
\hline $\begin{array}{c}\text { Histone } \\
\text { modifications }\end{array}$ & cfDNA ChIP-qPCR & $\mathrm{n} / \mathrm{a}$ & $\begin{array}{l}\text { Non-small cell lung cancer } \\
\qquad(n=14)\end{array}$ & $\begin{array}{l}\text { Correlation of } \mathrm{H} 3 \mathrm{~K} 36 \mathrm{me} 3 \\
\text { occupancy and gene expression } \\
\text { in lung cancer associated genes }\end{array}$ & [74] \\
\hline
\end{tabular}

WGS: whole genome sequencing.

Although still in its infancy, conceptually, cfChIP-seq might be used as a surrogate for gene expression and hence be informative of expression signatures that can trace the tissueof-origin of cfDNA. The potential clinical utility of this strategy includes estimation of tumor load, identification of cellular processes, and assessment of inter-tumor heterogeneity. One advantage of cfChIP-seq over nucleosome positioning approaches is the requirement of significantly fewer sequencing reads. Since ChIP parallels a targeted pulldown approach that reduces coverage of a large part of the genome, informative data can be acquired at lower sequencing costs.

In a proof of principle study, Vad-Nielsen et al. correlated the expression of lung cancer-associated genes with H3K36me3 enrichment in plasma via cfChIP [74]. H3K36me3 pulldown reflected the repression of $S A T 2$ and $A L K$, and the constitutive activation of ACGT1 in cfDNA derived from NSCLC patients. The authors also showed that differential expression of KRT6 paralogs in lung adenocarcinoma (LUAD) and lung squamous cell carcinoma (LUSC), as observed in published immunohistochemical and gene expression data, can be captured by H3K36me3 cfChIP. Despite these interesting data, the study remained exploratory and limited by its small sample size. Moreover, its application for cell-of-origin or tumor subtype identification requires specific markers with distinct and differential expression in the tissue or tumor of interest.

\section{Epigenomic Modifications of cfDNA}

Many studies have characterized epigenomic DNA patterns in tissues of cancer patients and healthy individuals [75-78], which were also found to be detectable in cfDNA. Their tissue specificity, which is largely retained in cfDNA $[79,80]$ and the high number of alterations in cancer, provide additional information that complements other liquid biopsy approaches (Figure 1).

\subsection{Methylation Profiling of cfDNA}

Recently, several studies used cfDNA methylation to deconvolute the contribution of various cell and tissue types to the cfDNA pool $[27,64,65,81]$. Sun et al. [65] applied whole genome bisulfite sequencing (WGBS) of cfDNA from 29 HCC patients, four liver transplant recipients, 15 pregnant women and 32 control subjects. Using reference methylomes from 
11 tissues and three blood cell types, they calculated that 70 to $90 \%$ of plasma DNA is derived from white blood cells, in particular lymphocytes and neutrophils. The contribution of tissue DNA to the cfDNA repertoire varied in accordance with each patient's physiological or pathological condition: liver transplant recipients and HCC patients demonstrated elevated levels of liver-derived cfDNA, whereas the placental DNA contribution was higher in pregnancy, when compared with the control group. These results demonstrated that tissue-specific methylation can be captured from cfDNA and that the contribution of different tissue types in such data can inform the presence of a tumor and its primary growth site. Moss et al. [64] took advantage of array-based tissue methylation data to generate a reference atlas comprising 25 cell and tissue types, including nine hematopoietic and endothelial cell types. Lymphocytes $(12.1 \%)$, granulocytes $(32.0 \%)$, monocytes $(10.5 \%)$ and erythroid progenitors $(29.7 \%)$ were identified to be major hematopoietic cells contributing to the cfDNA pool. DNA contributions from vascular endothelial cells $(8.6 \%)$ and hepatocytes $(1.2 \%)$ were also observed. The application of their deconvolution algorithm to cfDNA from cancer patients (i.e., breast, lung, and colon; $n=11$ ) resulted in correct classification of the majority of cases and identified associations with the response to therapy in prostate cancer patients. In four patients with cancers of unknown primary (CUPs), the deconvolution showed strong tissue-specificity, indicating the tumor's primary site. Despite these encouraging results, the practicability of this approach was limited by the requirement for a large quantity of cfDNA input material ( $100 \mathrm{ng})$ for array-based methylation analysis.

Apart from the tissue information presented by the cfDNA methylome, the high prevalence of $5 \mathrm{mC}$ alterations in cancer can be exploited for sensitive cancer detection and classification, even in early stages [82-88] (Table 3). Two recent studies [85,86], used an affinity-based methodology, termed "cell-free DNA methylation immunoprecipitation" (cfMeDIP-seq), to enrich and sequence methylated regions from plasma DNA. cfMeDIP-seq interrogates methylation events on a genome-wide scale and was previously demonstrated to sensitively detect and classify various cancer entities [89]. The method only requires minute amounts (1 to $10 \mathrm{ng}$ ) of cfDNA input material and is therefore potentially suitable in a clinical setting. Nassiri and Nuzzo et al. $[85,86]$ used cfMeDIP-seq data to train ML algorithms for the detection and classification of intracranial tumors as well as RCC from plasma and urinary cfDNA. Due to their low ctDNA shedding capacity, both tumor types are difficult to detect using liquid biopsies $[9,90]$. cfMeDIP-seq accurately detected intracranial tumors $(n=60)$ in a cohort of 447 plasma samples (AUC $=0.99)$, comprising eight tumor types and individuals without cancer [85]. Furthermore, common primary intracranial tumors (i.e., hemangiopericytoma, meningioma, low-grade glial-neuronal tumors, and gliomas; $n=161$ ), which are otherwise challenging to discern by magnetic resonance imaging, could be distinguished based on cfMeDIP-seq data. An ML classifier trained on cfDNA-based cfMeDIP-seq data from 97 individuals $(n=69$ RCC patients, $n=15$ urothelial bladder cancer patients (UBC), $n=133$ controls) separated RCC samples from the other two subgroups (RCC vs. controls: $A U C=0.99$; $R C C$ vs. $U B C$ : $A U C=0.98$ ). Urinary cfDNA-based classification ( $n=30$ RCC patients, $n=15$ controls) could also distinguish RCC from control samples (AUC $=0.86$ ) [86], albeit with lower accuracy. Of note, both plasma- and urine-based analyses included stage I and II RCC patients, further highlighting the practicality of cfMeDIP-seq in challenging clinical scenarios. Moreover, successful methylation analysis of urinary cfDNA demonstrates the utility of urine for genomic [34,91-93], as well as epigenomic analysis. DNA methylation marks have been detected in urine sediment in various cancer types such as bladder cancer [94], endometrial cancer [95], and prostate cancer [96]. Additionally, urinary cfDNA equally offers the opportunity for DNA methylation analysis in colorectal cancer [97], bladder cancer [98], and RCC [34].

Combining genomic and epigenomic analysis in assessing methylation status, CNA and cfDNA fragment analysis via shallow-depth bisulfite sequencing of urinary cfDNA, 
Cheng et al. were able to detect bladder cancer with overall sensitivity of $93.5 \%$ and specificity of $95.8 \%$ [98].

Another way to leverage the high sensitivity of methylation analyses from cfDNA is the utilization of targeted bisulfite sequencing panels. Here, the large number of publicly available reference methylomes paired with the understanding of the different cell types contributing to the plasma DNA pool is of substantial value. Several studies used tissueand blood cell-derived data to generate cancer-specific methylation sequencing panels. For instance, Moss et al. [84] designed a breast unique biomarker panel interrogating the methylation status of three genomic loci. The average signal of these markers could distinguish breast cancer patients (metastatic: $n=17$; localized: $n=30$ ) from healthy donors $(n=64)$ with high sensitivity and specificity $(80 \%$ and $97 \%$, respectively). In longitudinal plasma samples, the breast-specific methylation signature was also indicative of therapy response and the presence of residual disease. Similarly, a CRC-specific methylation panel, covering nine marker regions, demonstrated high accuracy for the detection of CRC (AUC $=0.96)$ [99]. Chen et al. [88] designed a larger sequencing panel $(10,613 \mathrm{CpGs}$ in 477 genomic regions) to allow simultaneous detection of multiple cancer entities. Training a logistic regression classifier on the panel-based methylation data, they predicted the presence of disease across five tumor types (i.e., lung, colorectal, liver, stomach, and esophagus) with a sensitivity of $88 \%$. Furthermore, they demonstrated that their tumor detection strategy might be eligible in a cancer screening scenario. In 143 asymptomatic individuals who were later diagnosed with cancer, the assay detected the disease up to four years prior to the clinical diagnosis (sensitivity: 95\%).

The Circulating Cell-free Genome Atlas (CCGA) study is a large scale $(n=8584$ cancer patients; $n=6670$ controls) ongoing clinical trial that aims to establish cfDNA sequencing for the detection and localization of multiple cancer entities. In the first part of the CCGA study, the interrogation of genome-wide methylation patterns (WGBS) outperformed the assessment of CNVs and SNVs by whole genome or targeted sequencing $[100,101]$. The second CCGA sub-study used a bisulfite sequencing panel (1.1 million CpGs in 103,456 regions) to detect and classify more than 50 primary tumor types in 2482 untreated cancer patients (all stages) and 4207 individuals without cancer. At a specificity of $99.3 \%$, the test yielded a sensitivity of $43.9 \%$ to detect cancers; the tissue-of-origin was correctly classified in $93 \%$ of cancer cases [83]. The third part of the CCGA study is a large clinical validation of this assay [102]. The multi-cancer early detection (MCED) validation study included 4077 participants in an independent cohort. The resulting specificity of the test for cancer signal detection was $99.5 \%$, and overall sensitivity was $51.5 \%$. Cancer signals were detected across $>50$ cancer types, and as expected, the test sensitivity increased with disease. Building on the success of the MCED, large clinical programs are ongoing to evaluate the performance in a screening population, assess clinical implementation and safety [103-105].

\subsection{5-hydroxymethylation Profiling of cfDNA}

$5 \mathrm{mC}$ can be reverted to its unmodified state by oxidation steps catalyzed by the teneleven translocation (TET) enzymes [106-109]. Despite its low abundance (5mC: $3-4 \%$ vs. $5 \mathrm{hmC}: 0.1-1 \%$ of all cytosines [110]), $5 \mathrm{hmC}$ is more than an intermediate state during DNA demethylation. 5hmC abundances can remain stable over several cell divisions and are associated with the activation of nearby genes [111,112]. $5 \mathrm{hmC}$ residues accumulate at borders of $\mathrm{CpG}$ islands and prevent $5 \mathrm{mC}$ from spreading inside a hypomethylated region [113-117]. Unlike $5 \mathrm{mC}$, absolute $5 \mathrm{hmC}$ abundances vary considerably between different tissue types [118], which might allow a more precise inference of the tissue-oforigin using $5 \mathrm{hmC}$ as a biomarker.

Altered hydroxymethylomes have been identified in all human cancer entities. Genome-wide reduction of $5 \mathrm{hmC}$ levels is a feature shared by most cancers $[119,120]$ and can be attributed to the impaired activity of TET enzymes, either through inactivating TET mutations or mechanisms inhibiting the catalytic activity of TET (e.g., unavailability 
of co-factors or mutations in IDH1/2 genes) [120-122]. In recent years, the analysis of $5 \mathrm{hmC}$ from cfDNA has gained traction (Table 3). Song et al. [123] developed a highly sensitive methodology capable of selective enrichment for hydroxymethylated DNA groups, termed "hydroxymethylation selective chemical labeling" (hMeSEAL). hMeSEAL has been widely applied for cfDNA-based $5 \mathrm{hmC}$ profiling in various tumor entities [124-132]. In a proof-of-concept study, hMeSEAL was used to profile $5 \mathrm{hmC}$ changes in 49 plasma samples from cancer patients. In lung cancer, global $5 \mathrm{hmC}$ levels decreased from low-stage to metastatic tumors. HCC patients could be successfully differentiated from healthy donors and HBV-positive subjects based on $5 \mathrm{hmC}$ levels within gene bodies. Loci identified to be hydroxymethylated in HCC contained several genes with increased expression in liver tissue. This observation was in line with the activating effect of $5 \mathrm{hmC}$ on transcription and supports the concept of $5 \mathrm{hmC}$ in cfDNA as a surrogate for non-invasive inference of gene expression. Furthermore, longitudinal monitoring of $5 \mathrm{hmC}$ patterns in HCC patients, following surgical tumor resection, indicated remission or progression of the disease. Finally, ML algorithms detected and differentiated lung, liver, and pancreas cancers based on their $5 \mathrm{hmC}$ profiles with prediction accuracies of up to $90 \%$ [130]. These promising results were corroborated by several successive studies applying hMeSEAL on multiple cancer types (i.e., B-cell lymphoma, lung, liver, colorectal, gastric, esophageal, breast, prostate, and thyroid cancer). The genome-wide $5 \mathrm{hmC}$ profiles were used to derive biomarker panels for cancer classification, stage prediction or early diagnosis [124,125,129-132].

Table 3. Epigenomic and hydroxymethylation alterations of cfDNA in cancer.

\begin{tabular}{|c|c|c|c|c|c|c|}
\hline $\begin{array}{c}\text { cfDNA } \\
\text { Modification }\end{array}$ & Method & Analyte & Control Cohort & Cancer Entity Tested & Result & Reference \\
\hline $5 \mathrm{mC}$ & $\begin{array}{l}\text { Illumina } 450 \mathrm{k} \\
\text { methylation array }\end{array}$ & Plasma & $\begin{array}{l}\text { Healthy control } \\
\text { cfDNA }(n=105) \\
\text { combined to } 8 \text { pools }\end{array}$ & $\begin{array}{c}\text { Colon }(n=4), \text { lung }(n=4), \\
\text { breast } \\
(n=3) \text { cancer, and CUP }(n=4)\end{array}$ & $\begin{array}{l}\text { Tissue-of-origin deconvolution } \\
\text { from cfDNA agrees with } \\
\text { clinical findings }\end{array}$ & [64] \\
\hline $5 \mathrm{mC}$ & $\begin{array}{c}\text { Affinity-based } \\
\text { profiling (cfMeDIP) }\end{array}$ & Plasma & $\begin{array}{l}\text { Healthy controls } \\
\quad(n=62)\end{array}$ & $\begin{array}{l}\text { Multiple cancer entities } \\
\qquad(n=189)\end{array}$ & $\begin{array}{c}\text { Robust detection and } \\
\text { classification across various } \\
\text { cancer types (AUC }=0.91-0.98 \\
\text { depending on entity and stage) }\end{array}$ & [87] \\
\hline $5 \mathrm{mC}$ & $\begin{array}{c}\text { Affinity-based } \\
\text { profiling (cfMeDIP) }\end{array}$ & Plasma & $\begin{array}{l}\text { Various extracranial } \\
\text { tumors and healthy } \\
\text { controls }(n=387)\end{array}$ & $\begin{array}{l}\text { Multiple intracranial tumor } \\
\text { types }(n=220)\end{array}$ & $\begin{array}{l}\text { Accurate detection }(\mathrm{AUC}=0.99) \\
\text { and discrimination of common } \\
\text { intracranial tumor types } \\
\text { (AUC }=0.71-0.95 \text { depending on } \\
\text { the type of brain tumor) }\end{array}$ & [85] \\
\hline $5 \mathrm{mC}$ & $\begin{array}{c}\text { Affinity-based } \\
\text { profiling (cfMeDIP) }\end{array}$ & $\begin{array}{l}\text { Plasma; } \\
\text { urine }\end{array}$ & $\begin{array}{l}\text { Healthy controls } \\
\text { ( } n=133 \text { plasma } \\
\text { samples; } n=15 \\
\text { urine samples) }\end{array}$ & $\begin{array}{l}\text { RCC ( } n=69 \text { plasma samples; } \\
n=30 \text { urine samples), UBC } \\
\qquad(n=15)\end{array}$ & $\begin{array}{l}\text { Detection of RCC patients } \\
\text { (plasma AUC }=0.99 ; \text { urine } \\
\text { AUC = 0.86) differentiation } \\
\text { between RCC and UBC (plasma } \\
\text { AUC }=0.98 \text { ) }\end{array}$ & [86] \\
\hline $5 \mathrm{mC}$ & $\begin{array}{l}\text { Targeted bisulfite } \\
\text { sequencing }\end{array}$ & Plasma & $\begin{array}{l}\text { Healthy controls } \\
\quad(n=64)\end{array}$ & $\begin{array}{c}\text { Localized }(n=30) \text { and } \\
\text { metastatic } \\
(n=17) \text { breast cancer patients }\end{array}$ & $\begin{array}{c}\text { Cancer detection and therapy } \\
\text { surveillance based on a } \\
\text { breast-unique 3-marker } \\
\text { methylation panel }\end{array}$ & [84] \\
\hline $5 \mathrm{mC}$ & $\begin{array}{l}\text { Targeted bisulfite } \\
\text { sequencing } \\
\text { (PanSeer) }\end{array}$ & Plasma & $\begin{array}{l}\text { Asymptotic } \\
\text { individuals } \\
\quad(n=414)\end{array}$ & $\begin{array}{c}\text { Cancer patients } \\
(n=223) \text { and asymptotic } \\
\text { individuals that were later } \\
\text { diagnosed with cancer } \\
(n=191)\end{array}$ & $\begin{array}{l}\text { Cancer detection (up to four } \\
\text { years prior to diagnosis) across } \\
\text { five cancer entities using a } \\
\text { methylation panel covering } \\
447 \text { genomic loci }\end{array}$ & [88] \\
\hline $5 \mathrm{mC}$ & $\begin{array}{l}\text { Targeted bisulfite } \\
\text { sequencing }\end{array}$ & Plasma & $\begin{array}{l}\text { Healthy controls } \\
\quad(n=4207)\end{array}$ & $>50$ cancer entities $(n=2482)$ & $\begin{array}{c}\text { Cancer detection in }>50 \text { entities } \\
\text { with a specificity of } 99.3 \% \text { and } \\
\text { accurate tissue-of-origin } \\
\text { prediction in } 93 \% \text { of cases }\end{array}$ & [83] \\
\hline $5 \mathrm{hmC}$ & $\begin{array}{l}\text { Affinity-based } \\
\text { profiling } \\
\text { (hMeSEAL) }\end{array}$ & Plasma & $\begin{array}{l}\text { Healthy controls } \\
\qquad \begin{array}{c}(n=8), \mathrm{HBV} \\
(n=7)\end{array}\end{array}$ & $\begin{array}{c}\text { Lung }(n=15), \text { pancreatic }(n=7), \\
\text { gastric }(n=5), \text { breast cancer } \\
(n=4), \operatorname{HCC}(n=10), \text { CRC } \\
(n=4), \text { and glioblastoma }(n=4)\end{array}$ & $\begin{array}{l}\text { Detection of disease/stage } \\
\text { specific } 5 \mathrm{hmC} \text { changes capable } \\
\text { of differentiating lung, liver, } \\
\text { and pancreatic cancers }\end{array}$ & [130] \\
\hline $5 \mathrm{hmC}$ & $\begin{array}{l}\text { Affinity-based } \\
\text { profiling } \\
\text { (hMeSEAL) }\end{array}$ & Plasma & $\begin{array}{l}\text { Healthy controls } \\
\qquad(n=243)\end{array}$ & Pancreatic cancer $(n=64)$ & $\begin{array}{c}\text { Classification of pancreatic } \\
\text { cancer patients based on } 5 \mathrm{hmC} \\
\text { features }(\mathrm{AUC}=0.88)\end{array}$ & [129] \\
\hline $5 \mathrm{hmC}$ & $\begin{array}{l}\text { Affinity-based } \\
\text { profiling } \\
\text { (hMeSEAL) }\end{array}$ & Plasma & $\begin{array}{l}\text { Healthy controls } \\
\quad(n=177)\end{array}$ & Esophageal cancer $(n=150)$ & $\begin{array}{c}5 \mathrm{hmC} \text { signature-based } \\
\text { detection of esophageal cancer } \\
(\mathrm{AUC}=0.96)\end{array}$ & [131] \\
\hline
\end{tabular}

AUC, area under the curve; CUP, cancer of unknown primary; HCC, hepatocellular carcinoma; RCC, renal cell carcinoma; UBC, urothelial bladder cancer. 


\section{Combinatorial Biomarkers for cfDNA Analysis}

Epigenomic changes are readily observed at early stages of tumor development $[30,133]$, opening up their potential as diagnostic tools for early cancer detection, risk stratification and MRD. Nevertheless, many liquid biopsy-based assays suffer from reduced sensitivity due to low levels of ctDNA. One promising way to mitigate this obstacle and to increase the detection success is to screen for multiple targets and combine multi-analyte analysis.

Cai and colleagues [126] combined a 5hmC signature (based on 64 loci) with existing diagnostic protein markers (AFP and DCP) to differentiate $135 \mathrm{HCC}$ patients from 165 healthy donors and 62 liver cirrhosis patients. Their diagnostic score ("HCC score"), based on the two marker types, identified HCC patients with an AUC $=0.93$ and was correlated with the TNM classification of the tumors. Moreover, the HCC score was indicative of recurrence following surgical tumor resection, and reflected the dynamics of tumor burden in patients with long-term follow-up plasma samples. Another study combined hMeSEAL-based $5 \mathrm{hmC}$ with cfMeDIP-seq-based $5 \mathrm{hmC}$ profiling. The combination of these biomarkers improved the diagnostic power for the detection of pancreatic cancer compared with using $5 \mathrm{mC}$ or $5 \mathrm{hmC}$ marker panels alone [127].

Peneder et al. [134] performed a multimodal analysis of cfDNA to overcome the obstacle of low mutational burden in paediatric patients with predominantly Ewing Sarcoma (EwS). Applying deep WGS on 263 cfDNA samples from patients with EwS $(n=95)$, other pediatric sarcomas $(n=31)$, and healthy controls $(n=22)$, they combined copy number alterations, the presence of the EWS-ETS fusion oncogene and cfDNA fragment size distributions. The integrated genetic analysis of CNVs and the detection of the EWS-ETS fusion gene served for the quantification of the tumor content in cfDNA. Similar to previously mentioned reports, they found that tumor patients harbored a significantly higher proportion of shorter cfDNA fragments $<150 \mathrm{bp}$ compared with healthy controls. Combining fragment and genetic analysis, this higher proportion of smaller cfDNA fragments was equally detectable in patient samples in which evidence for ctDNA was missing or only the EWS-ETS fusion gene but no CNVs were detected. Fragment size selection further improved CNV analysis and supported the evaluation of CNV dynamics over the disease courses in a subset of the patients. cfDNA samples from EwS patients showed particular position-dependent short to long fragment $(\mathrm{S} / \mathrm{L})$ ratios in genome-wide 100-kb bins. By aligning bins with a higher proportion of shorter fragments to regions with known epigenetic and transcription-regulation alterations, an enrichment of regions with EwSassociated open chromatin was found. Finally, based on a ML algorithm and the presented fragmentation analysis methods, cfDNA from EwS patients could be distinguished from healthy controls with high sensitivity and specificity. This study highlighted opportunities for data integration by applying several assays on the same starting material (i.e., cfDNA).

\section{Challenges and Future Directions}

Liquid biopsies are becoming increasingly important in the serial profiling and individualized management of malignant diseases. At present, clinically-approved ctDNA assays act as companion diagnostics that facilitate therapy guidance based on genetic alterations including SNVs, amplifications, insertions/deletions, and translocations [135]. Despite their clinical relevance, the information that can be gained from cfDNA could be significantly enhanced by including epigenomic analyses, as outlined here. One step in this direction is represented by low throughput ctDNA methylation assays, which survey the epigenomic status of validated biomarkers in bladder, breast, colorectal, cervical, lung, and prostate cancers [136] with the intention of disease detection and therapy response prediction. Another advantage of epigenomic ctDNA analyses, particularly of those that generate $5 \mathrm{mC}$ and $5 \mathrm{hmC}$ data, is the declining sequencing cost. At the appropriate sequencing depth, relevant methylation or hydroxymethylation biomarkers can be identified in a single reaction. The overall cost of these assays can be further reduced through the design of hybridization probes to capture regions of interest. Several cfDNA technologies presented here involve enrichment of genomic targets through antibody- (e.g., MeDIP-seq, ChIP-seq) 
or chemical affinity-based (e.g., hMeSeal-seq) approaches. As a consequence of target enrichment, moderate sequencing depths of precipitated DNA are sufficient. In contrast, mutation analysis requires high on-target coverage for ctDNA detection and therefore high cost. Furthermore, the epigenomic approaches reviewed here do not necessitate high amounts of input DNA, allowing their application even when cfDNA concentrations are low (e.g., in patients with localized disease).

There are still a number of challenges that must be met prior to a clinical translation of epigenomic ctDNA analyses. While many proof-of-principle studies have shown that fragmentomics, nucleosome positioning, and ChIP-seq of cfDNA can identify the cell(s)of-origin and possibly differentiate disease stages, there is still a lack of validation of these methods in larger multicenter clinical studies. Another challenge lies in the high quantities of non-tumor cfDNA in cancer patients, which is mostly derived from leukocytes. Extensive bioinformatic expertise is required to discern epigenomic cancer markers from the non-tumor background. Considerable opportunities beyond the epigenomic analysis of cfDNA reside in the inclusion of other molecular analytes from blood or plasma, such as circulating tumor cells (CTCs), mRNA, miRNA, and extracellular vesicles. CTCs in particular have been utilized to demonstrate intrapatient heterogeneity which could explain therapy resistance [137], and to explore the biological mechanisms underlying cancer cell dissemination [138]. CTC quantification has also been shown to be informative of therapy response in breast [139], prostate [140], and bladder [141] cancers. The analysis of other body fluids (e.g., urine, saliva, CSF) could further improve patient management.

\section{Conclusions}

Liquid biopsies in cancer have advanced from DNA mutations to the epigenome. In contrast to somatic genetic mutations, epigenetic features are more dynamic, with the potential of closely reflecting recent physiological alterations. Although challenges remain, the low amounts of DNA required, the large number of possible markers, and the comparatively low per-sample cost are substantial advantages of epigenomic analyses. The integration of different non-invasive markers opens new prospects and augments current established methods for cancer patient stratification, treatment decision and response prediction, timely identification of minimal residual disease and tumor recurrence, as well as early detection.

Author Contributions: Conceptualization, A.K.A., F.J., S.B. and H.S.; formal analysis, A.K.A., F.J. and S.B.; investigation, A.K.A., F.J., S.B., P.C., A.L.R. and H.S.; data curation, A.K.A., F.J. and S.B.; writing-review and editing, A.K.A., F.J., S.B., P.C., A.L.R. and H.S.; visualization, A.K.A., F.J. and S.B.; supervision, H.S.; project administration, H.S.; funding acquisition, H.S.; A.K.A., F.J., and S.B. contributed equally to this work. All authors have read and agreed to the published version of the manuscript.

Funding: This work was supported by internal funding from the German Cancer Research Center.

Conflicts of Interest: The authors declare no conflict of interest.

\section{References}

1. De Vlaminck, I.; Valantine, H.A.; Snyder, T.M.; Strehl, C.; Cohen, G.; Luikart, H.; Neff, N.F.; Okamoto, J.; Bernstein, D.; Weisshaar, D. Circulating cell-free DNA enables noninvasive diagnosis of heart transplant rejection. Sci. Transl. Med. 2014, 6, 241ra77. [CrossRef]

2. De Vlaminck, I.; Martin, L.; Kertesz, M.; Patel, K.; Kowarsky, M.; Strehl, C.; Cohen, G.; Luikart, H.; Neff, N.F.; Okamoto, J. Noninvasive monitoring of infection and rejection after lung transplantation. Proc. Natl. Acad. Sci. USA 2015, 112, 13336-13341. [CrossRef]

3. Snyder, T.M.; Khush, K.K.; Valantine, H.A.; Quake, S.R. Universal noninvasive detection of solid organ transplant rejection. Proc. Natl. Acad. Sci. USA 2011, 108, 6229-6234. [CrossRef]

4. Chiu, R.W.; Chan, K.C.; Gao, Y.; Lau, V.Y.; Zheng, W.; Leung, T.Y.; Foo, C.H.; Xie, B.; Tsui, N.B.; Lun, F.M.; et al. Noninvasive prenatal diagnosis of fetal chromosomal aneuploidy by massively parallel genomic sequencing of DNA in maternal plasma. Proc. Natl. Acad. Sci. USA 2008, 105, 20458-20463. [CrossRef] 
5. Fan, H.C.; Blumenfeld, Y.J.; Chitkara, U.; Hudgins, L.; Quake, S.R. Noninvasive diagnosis of fetal aneuploidy by shotgun sequencing DNA from maternal blood. Proc. Natl. Acad. Sci. USA 2008, 105, 16266-16271. [CrossRef] [PubMed]

6. Andersson, A.K.; Ma, J.; Wang, J.; Chen, X.; Gedman, A.L.; Dang, J.; Nakitandwe, J.; Holmfeldt, L.; Parker, M.; Easton, J. The landscape of somatic mutations in infant MLL-rearranged acute lymphoblastic leukemias. Nat. Genet. $2015,47,330-337$. [CrossRef]

7. Gerlinger, M.; Rowan, A.J.; Horswell, S.; Larkin, J.; Endesfelder, D.; Gronroos, E.; Martinez, P.; Matthews, N.; Stewart, A.; Tarpey, P. Intratumor heterogeneity and branched evolution revealed by multiregion sequencing. N. Engl. J. Med. 2012, 366, 883-892. [CrossRef]

8. Snyder, M.W.; Kircher, M.; Hill, A.J.; Daza, R.M.; Shendure, J. Cell-free DNA comprises an in vivo nucleosome footprint that informs its tissues-of-origin. Cell 2016, 164, 57-68. [CrossRef]

9. Bettegowda, C.; Sausen, M.; Leary, R.J.; Kinde, I.; Wang, Y.; Agrawal, N.; Bartlett, B.R.; Wang, H.; Luber, B.; Alani, R.M.; et al. Detection of circulating tumor DNA in early- and late-stage human malignancies. Sci. Transl. Med. 2014, 6, 224ra224. [CrossRef] [PubMed]

10. Hellmann, M.D.; Nabet, B.Y.; Rizvi, H.; Chaudhuri, A.A.; Wells, D.K.; Dunphy, M.P.S.; Chabon, J.J.; Liu, C.L.; Hui, A.B.; Arbour, K.C.; et al. Circulating Tumor DNA Analysis to Assess Risk of Progression after Long-term Response to PD-(L)1 Blockade in NSCLC. Clin. Cancer Res. 2020, 26, 2849-2858. [CrossRef]

11. Diaz, L.A., Jr.; Bardelli, A. Liquid biopsies: Genotyping circulating tumor DNA. J. Clin. Oncol. 2014, 32, 579-586. [CrossRef]

12. Van der Pol, Y.; Mouliere, F. Toward the Early Detection of Cancer by Decoding the Epigenetic and Environmental Fingerprints of Cell-Free DNA. Cancer Cell 2019, 36, 350-368. [CrossRef]

13. Ottaviano, M.; Giuliano, M.; Tortora, M.; La Civita, E.; Liotti, A.; Longo, M.; Bruzzese, D.; Cennamo, M.; Riccio, V.; De Placido, P.; et al. A New Horizon of Liquid Biopsy in Thymic Epithelial Tumors: The Potential Utility of Circulating Cell-Free DNA. Front. Oncol. 2020, 10, 602153. [CrossRef]

14. Christopoulos, P.; Dietz, S.; Angeles, A.K.; Rheinheimer, S.; Kazdal, D.; Volckmar, A.L.; Janke, F.; Endris, V.; Meister, M.; Kriegsmann, M.; et al. Earlier extracranial progression and shorter survival in ALK-rearranged lung cancer with positive liquid rebiopsies. Transl. Lung Cancer Res. 2021, 10, 2118-2131. [CrossRef]

15. Dietz, S.; Christopoulos, P.; Yuan, Z.; Angeles, A.K.; Gu, L.; Volckmar, A.-L.; Ogrodnik, S.J.; Janke, F.; Dalle Fratte, C.; Zemojtel, T. Longitudinal therapy monitoring of ALK-positive lung cancer by combined copy number and targeted mutation profiling of cell-free DNA. EBioMedicine 2020, 62, 103103. [CrossRef] [PubMed]

16. Angeles, A.K.; Christopoulos, P.; Yuan, Z.; Bauer, S.; Janke, F.; Ogrodnik, S.J.; Schlesner, M.; Reck, M.; Meister, M.; Schneider, M.; et al. Early identification of disease progression in ALK-rearranged lung cancer using circulating tumor DNA analysis. NPJ Precis. Oncol. in press. 2021.

17. Le Guin, C.H.D.; Bornfeld, N.; Bechrakis, N.E.; Jabbarli, L.; Richly, H.; Lohmann, D.R.; Zeschnigk, M. Early detection of metastatic uveal melanoma by the analysis of tumor-specific mutations in cell-free plasma DNA. Cancer Med. 2021, 10, 5974-5982. [CrossRef]

18. Kim, Y.W.; Kim, Y.H.; Song, Y.; Kim, H.S.; Sim, H.W.; Poojan, S.; Eom, B.W.; Kook, M.C.; Joo, J.; Hong, K.M. Monitoring circulating tumor DNA by analyzing personalized cancer-specific rearrangements to detect recurrence in gastric cancer. Exp. Mol. Med. 2019, 51, 1-10. [CrossRef] [PubMed]

19. Wan, J.C.M.; Massie, C.; Garcia-Corbacho, J.; Mouliere, F.; Brenton, J.D.; Caldas, C.; Pacey, S.; Baird, R.; Rosenfeld, N. Liquid biopsies come of age: Towards implementation of circulating tumour DNA. Nat. Rev. Cancer 2017, 17, 223-238. [CrossRef]

20. Heitzer, E.; Haque, I.S.; Roberts, C.E.S.; Speicher, M.R. Current and future perspectives of liquid biopsies in genomics-driven oncology. Nat. Rev. Genet. 2019, 20, 71-88. [CrossRef]

21. Feinberg, A.P.; Koldobskiy, M.A.; Gondor, A. Epigenetic modulators, modifiers and mediators in cancer aetiology and progression. Nat. Rev. Genet. 2016, 17, 284-299. [CrossRef]

22. Lokk, K.; Modhukur, V.; Rajashekar, B.; Märtens, K.; Mägi, R.; Kolde, R.; Koltšina, M.; Nilsson, T.K.; Vilo, J.; Salumets, A. DNA methylome profiling of human tissues identifies global and tissue-specific methylation patterns. Genome Biol. 2014, $15,3248$. [CrossRef]

23. Ponnaluri, V.C.; Ehrlich, K.C.; Zhang, G.; Lacey, M.; Johnston, D.; Pradhan, S.; Ehrlich, M. Association of 5-hydroxymethylation and 5-methylation of DNA cytosine with tissue-specific gene expression. Epigenetics 2017, 12, 123-138. [CrossRef]

24. De Gobbi, M.; Anguita, E.; Hughes, J.; Sloane-Stanley, J.A.; Sharpe, J.A.; Koch, C.M.; Dunham, I.; Gibbons, R.J.; Wood, W.G.; Higgs, D.R. Tissue-specific histone modification and transcription factor binding in $\alpha$ globin gene expression. Blood 2007, 110, 4503-4510. [CrossRef]

25. Esteller, M. Cancer epigenomics: DNA methylomes and histone-modification maps. Nat. Rev. Genet. 2007, 8, 286-298. [CrossRef] [PubMed]

26. Zhong, S.; He, X.; Bar-Joseph, Z. Predicting tissue specific transcription factor binding sites. BMC Genom. 2013, 14, 796. [CrossRef]

27. Lehmann-Werman, R.; Neiman, D.; Zemmour, H.; Moss, J.; Magenheim, J.; Vaknin-Dembinsky, A.; Rubertsson, S.; Nellgård, B.; Blennow, K.; Zetterberg, H.; et al. Identification of tissue-specific cell death using methylation patterns of circulating DNA. Proc. Natl. Acad. Sci. USA 2016, 113, E1826-E1834. [CrossRef]

28. Kang, S.; Li, Q.; Chen, Q.; Zhou, Y.; Park, S.; Lee, G.; Grimes, B.; Krysan, K.; Yu, M.; Wang, W. CancerLocator: Non-invasive cancer diagnosis and tissue-of-origin prediction using methylation profiles of cell-free DNA. Genome Biol. 2017, 18, 53. [CrossRef] 
29. Sadeh, R.; Sharkia, I.; Fialkoff, G.; Rahat, A.; Gutin, J.; Chappleboim, A.; Nitzan, M.; Fox-Fisher, I.; Neiman, D.; Meler, G.; et al. ChIP-seq of plasma cell-free nucleosomes identifies gene expression programs of the cells of origin. Nat. Biotechnol. 2021, 39, 586-598. [CrossRef]

30. Church, T.R.; Wandell, M.; Lofton-Day, C.; Mongin, S.J.; Burger, M.; Payne, S.R.; Castanos-Velez, E.; Blumenstein, B.A.; Rosch, T.; Osborn, N.; et al. Prospective evaluation of methylated SEPT9 in plasma for detection of asymptomatic colorectal cancer. Gut 2014, 63, 317-325. [CrossRef]

31. Powrózek, T.; Krawczyk, P.; Kucharczyk, T.; Milanowski, J. Septin 9 promoter region methylation in free circulating DNAPotential role in noninvasive diagnosis of lung cancer: Preliminary report. Med Oncol. 2014, 31, 917. [CrossRef]

32. Hennigan, S.T.; Trostel, S.Y.; Terrigino, N.T.; Voznesensky, O.S.; Schaefer, R.J.; Whitlock, N.C.; Wilkinson, S.; Carrabba, N.V.; Atway, R.; Shema, S.; et al. Low Abundance of Circulating Tumor DNA in Localized Prostate Cancer. JCO Precis. Oncol. 2019, 3, 1-13. [CrossRef]

33. Piccioni, D.E.; Achrol, A.S.; Kiedrowski, L.A.; Banks, K.C.; Boucher, N.; Barkhoudarian, G.; Kelly, D.F.; Juarez, T.; Lanman, R.B.; Raymond, V.M.; et al. Analysis of cell-free circulating tumor DNA in 419 patients with glioblastoma and other primary brain tumors. CNS Oncol. 2019, 8, CNS34. [CrossRef]

34. Smith, C.G.; Moser, T.; Mouliere, F.; Field-Rayner, J.; Eldridge, M.; Riediger, A.L.; Chandrananda, D.; Heider, K.; Wan, J.C.M.; Warren, A.Y.; et al. Comprehensive characterization of cell-free tumor DNA in plasma and urine of patients with renal tumors. Genome Med. 2020, 12, 23. [CrossRef]

35. Phallen, J.; Sausen, M.; Adleff, V.; Leal, A.; Hruban, C.; White, J.; Anagnostou, V.; Fiksel, J.; Cristiano, S.; Papp, E. Direct detection of early-stage cancers using circulating tumor DNA. Sci. Transl. Med. 2017, 9, eaan2415. [CrossRef]

36. Jahr, S.; Hentze, H.; Englisch, S.; Hardt, D.; Fackelmayer, F.O.; Hesch, R.D.; Knippers, R. DNA fragments in the blood plasma of cancer patients: Quantitations and evidence for their origin from apoptotic and necrotic cells. Cancer Res. 2001, 61, $1659-1665$.

37. Cristiano, S.; Leal, A.; Phallen, J.; Fiksel, J.; Adleff, V.; Bruhm, D.C.; Jensen, S.Ø.; Medina, J.E.; Hruban, C.; White, J.R.; et al. Genome-wide cell-free DNA fragmentation in patients with cancer. Nature 2019, 570, 385-389. [CrossRef]

38. Hellwig, S.; Nix, D.A.; Gligorich, K.M.; O’Shea, J.M.; Thomas, A.; Fuertes, C.L.; Bhetariya, P.J.; Marth, G.T.; Bronner, M.P.; Underhill, H.R. Automated size selection for short cell-free DNA fragments enriches for circulating tumor DNA and improves error correction during next generation sequencing. PLoS ONE 2018, 13, e0197333. [CrossRef]

39. Chan, R.W.Y.; Serpas, L.; Ni, M.; Volpi, S.; Hiraki, L.T.; Tam, L.S.; Rashidfarrokhi, A.; Wong, P.C.H.; Tam, L.H.P.; Wang, Y.; et al. Plasma DNA Profile Associated with DNASE1L3 Gene Mutations: Clinical Observations, Relationships to Nuclease Substrate Preference, and In Vivo Correction. Am. J. Hum. Genet. 2020, 107, 882-894. [CrossRef]

40. Cheng, T.H.T.; Lui, K.O.; Peng, X.L.; Cheng, S.H.; Jiang, P.; Chan, K.C.A.; Chiu, R.W.K.; Lo, Y.M.D. DNase1 Does Not Appear to Play a Major Role in the Fragmentation of Plasma DNA in a Knockout Mouse Model. Clin. Chem. 2018, 64, 406-408. [CrossRef]

41. Mouliere, F.; Chandrananda, D.; Piskorz, A.M.; Moore, E.K.; Morris, J.; Ahlborn, L.B.; Mair, R.; Goranova, T.; Marass, F.; Heider, K.; et al. Enhanced detection of circulating tumor DNA by fragment size analysis. Sci. Transl. Med. 2018, 10, eaat4921. [CrossRef]

42. Jiang, P.; Chan, C.W.M.; Chan, K.C.A.; Cheng, S.H.; Wong, J.; Wong, V.W.-S.; Wong, G.L.H.; Chan, S.L.; Mok, T.S.K.; Chan, H.L.Y.; et al. Lengthening and shortening of plasma DNA in hepatocellular carcinoma patients. Proc. Natl. Acad. Sci. USA 2015, 112, E1317-E1325. [CrossRef]

43. Chan, K.C.; Zhang, J.; Hui, A.B.; Wong, N.; Lau, T.K.; Leung, T.N.; Lo, K.W.; Huang, D.W.; Lo, Y.M. Size distributions of maternal and fetal DNA in maternal plasma. Clin. Chem. 2004, 50, 88-92. [CrossRef]

44. Lo, Y.M.; Chan, K.C.; Sun, H.; Chen, E.Z.; Jiang, P.; Lun, F.M.; Zheng, Y.W.; Leung, T.Y.; Lau, T.K.; Cantor, C.R.; et al. Maternal plasma DNA sequencing reveals the genome-wide genetic and mutational profile of the fetus. Sci. Transl. Med. 2010, 2, 61ra91. [CrossRef]

45. Zheng, Y.W.; Chan, K.C.; Sun, H.; Jiang, P.; Su, X.; Chen, E.Z.; Lun, F.M.; Hung, E.C.; Lee, V.; Wong, J.; et al. Nonhematopoietically derived DNA is shorter than hematopoietically derived DNA in plasma: A transplantation model. Clin. Chem. 2012, 58, 549-558. [CrossRef]

46. Jensen, T.J.; Kim, S.K.; Zhu, Z.; Chin, C.; Gebhard, C.; Lu, T.; Deciu, C.; van den Boom, D.; Ehrich, M. Whole genome bisulfite sequencing of cell-free DNA and its cellular contributors uncovers placenta hypomethylated domains. Genome Biol. 2015, 16, 78. [CrossRef]

47. Lun, F.M.; Chiu, R.W.; Sun, K.; Leung, T.Y.; Jiang, P.; Chan, K.C.; Sun, H.; Lo, Y.M. Noninvasive prenatal methylomic analysis by genomewide bisulfite sequencing of maternal plasma DNA. Clin. Chem. 2013, 59, 1583-1594. [CrossRef]

48. Kelly, T.K.; Liu, Y.; Lay, F.D.; Liang, G.; Berman, B.P.; Jones, P.A. Genome-wide mapping of nucleosome positioning and DNA methylation within individual DNA molecules. Genome Res. 2012, 22, 2497-2506. [CrossRef]

49. Mouliere, F.; Piskorz, A.M.; Chandrananda, D.; Moore, E.; Morris, J.; Smith, C.G.; Goranova, T.; Heider, K.; Mair, R.; Supernat, A.; et al. Selecting short DNA fragments in plasma improves detection of circulating tumour DNA. bioRxiv 2017, 134437. [CrossRef]

50. Underhill, H.R.; Kitzman, J.O.; Hellwig, S.; Welker, N.C.; Daza, R.; Baker, D.N.; Gligorich, K.M.; Rostomily, R.C.; Bronner, M.P.; Shendure, J. Fragment Length of Circulating Tumor DNA. PLoS Genet. 2016, 12, e1006162. [CrossRef] [PubMed]

51. Mouliere, F.; Mair, R.; Chandrananda, D.; Marass, F.; Smith, C.G.; Su, J.; Morris, J.; Watts, C.; Brindle, K.M.; Rosenfeld, N. Detection of cell-free DNA fragmentation and copy number alterations in cerebrospinal fluid from glioma patients. EMBO Mol. Med. 2018, 10, e9323. [CrossRef] 
52. Burnham, P.; Kim, M.S.; Agbor-Enoh, S.; Luikart, H.; Valantine, H.A.; Khush, K.K.; De Vlaminck, I. Single-stranded DNA library preparation uncovers the origin and diversity of ultrashort cell-free DNA in plasma. Sci. Rep. 2016, 6, 27859. [CrossRef]

53. Sanchez, C.; Roch, B.; Mazard, T.; Blache, P.; Al Amir Dache, Z.; Pastor, B.; Pisareva, E.; Tanos, R.; Thierry, A.R. Circulating nuclear DNA structural features, origins, and complete size profile revealed by fragmentomics. JCI Insight 2021, 6, e144561. [CrossRef]

54. Sanchez, C.; Snyder, M.W.; Tanos, R.; Shendure, J.; Thierry, A.R. New insights into structural features and optimal detection of circulating tumor DNA determined by single-strand DNA analysis. NPJ Genom. Med. 2018, 3, 31. [CrossRef]

55. Chan, K.C.; Jiang, P.; Sun, K.; Cheng, Y.K.; Tong, Y.K.; Cheng, S.H.; Wong, A.I.; Hudecova, I.; Leung, T.Y.; Chiu, R.W.; et al. Second generation noninvasive fetal genome analysis reveals de novo mutations, single-base parental inheritance, and preferred DNA ends. Proc. Natl. Acad. Sci. USA 2016, 113, E8159-E8168. [CrossRef]

56. Jiang, P.; Sun, K.; Tong, Y.K.; Cheng, S.H.; Cheng, T.H.T.; Heung, M.M.S.; Wong, J.; Wong, V.W.S.; Chan, H.L.Y.; Chan, K.C.A.; et al. Preferred end coordinates and somatic variants as signatures of circulating tumor DNA associated with hepatocellular carcinoma. Proc. Natl. Acad. Sci. USA 2018, 115, E10925-E10933. [CrossRef]

57. Chandrananda, D.; Thorne, N.P.; Bahlo, M. High-resolution characterization of sequence signatures due to non-random cleavage of cell-free DNA. BMC Med. Genom. 2015, 8, 29. [CrossRef]

58. Serpas, L.; Chan, R.W.Y.; Jiang, P.; Ni, M.; Sun, K.; Rashidfarrokhi, A.; Soni, C.; Sisirak, V.; Lee, W.-S.; Cheng, S.H.; et al. Dnase113 deletion causes aberrations in length and end-motif frequencies in plasma DNA. Proc. Natl. Acad. Sci. USA 2019, 116, 641-649. [CrossRef] [PubMed]

59. Han, D.S.C.; Ni, M.; Chan, R.W.Y.; Chan, V.W.H.; Lui, K.O.; Chiu, R.W.K.; Lo, Y.M.D. The Biology of Cell-free DNA Fragmentation and the Roles of DNASE1, DNASE1L3, and DFFB. Am. J. Hum. Genet. 2020, 106, 202-214. [CrossRef]

60. Jiang, P.; Xie, T.; Ding, S.C.; Zhou, Z.; Cheng, S.H.; Chan, R.W.Y.; Lee, W.S.; Peng, W.; Wong, J.; Wong, V.W.S.; et al. Detection and characterization of jagged ends of double-stranded DNA in plasma. Genome Res. 2020, 30, 1144-1153. [CrossRef]

61. Zhou, Z.; Cheng, S.H.; Ding, S.C.; Heung, M.M.S.; Xie, T.; Cheng, T.H.T.; Lam, W.K.J.; Peng, W.; Teoh, J.Y.C.; Chiu, P.K.F.; et al. Jagged Ends of Urinary Cell-Free DNA: Characterization and Feasibility Assessment in Bladder Cancer Detection. Clin. Chem. 2021, 67, 621-630. [CrossRef]

62. Sun, K.; Jiang, P.; Wong, A.I.C.; Cheng, Y.K.Y.; Cheng, S.H.; Zhang, H.; Chan, K.C.A.; Leung, T.Y.; Chiu, R.W.K.; Lo, Y.M.D Size-tagged preferred ends in maternal plasma DNA shed light on the production mechanism and show utility in noninvasive prenatal testing. Proc. Natl. Acad. Sci. USA 2018, 115, E5106-E5114. [CrossRef]

63. Ulz, P.; Thallinger, G.G.; Auer, M.; Graf, R.; Kashofer, K.; Jahn, S.W.; Abete, L.; Pristauz, G.; Petru, E.; Geigl, J.B.; et al. Inferring expressed genes by whole-genome sequencing of plasma DNA. Nat. Genet. 2016, 48, 1273-1278. [CrossRef]

64. Moss, J.; Magenheim, J.; Neiman, D.; Zemmour, H.; Loyfer, N.; Korach, A.; Samet, Y.; Maoz, M.; Druid, H.; Arner, P.; et al. Comprehensive human cell-type methylation atlas reveals origins of circulating cell-free DNA in health and disease. Nat. Commun. 2018, 9, 5068. [CrossRef] [PubMed]

65. Sun, K.; Jiang, P.; Chan, K.C.; Wong, J.; Cheng, Y.K.; Liang, R.H.; Chan, W.K.; Ma, E.S.; Chan, S.L.; Cheng, S.H.; et al. Plasma DNA tissue mapping by genome-wide methylation sequencing for noninvasive prenatal, cancer, and transplantation assessments. Proc. Natl. Acad. Sci. USA 2015, 112, E5503-E5512. [CrossRef]

66. Napirei, M.; Ludwig, S.; Mezrhab, J.; Klöckl, T.; Mannherz, H.G. Murine serum nucleases—Contrasting effects of plasmin and heparin on the activities of DNase1 and DNase1-like 3 (DNase113). FEBS J. 2009, 276, 1059-1073. [CrossRef]

67. Jiang, P.; Sun, K.; Peng, W.; Cheng, S.H.; Ni, M.; Yeung, P.C.; Heung, M.M.S.; Xie, T.; Shang, H.; Zhou, Z.; et al. Plasma DNA End-Motif Profiling as a Fragmentomic Marker in Cancer, Pregnancy, and Transplantation. Cancer Discov. 2020, 10, 664-673. [CrossRef]

68. Valouev, A.; Johnson, S.M.; Boyd, S.D.; Smith, C.L.; Fire, A.Z.; Sidow, A. Determinants of nucleosome organization in primary human cells. Nature 2011, 474, 516-520. [CrossRef]

69. Teif, V.B.; Vainshtein, Y.; Caudron-Herger, M.; Mallm, J.P.; Marth, C.; Hofer, T.; Rippe, K. Genome-wide nucleosome positioning during embryonic stem cell development. Nat. Struct. Mol. Biol. 2012, 19, 1185-1192. [CrossRef]

70. Murtaza, M.; Caldas, C. Nucleosome mapping in plasma DNA predicts cancer gene expression. Nat. Genet. 2016, 48, 1105-1106. [CrossRef]

71. Sun, K.; Jiang, P.; Cheng, S.H.; Cheng, T.H.T.; Wong, J.; Wong, V.W.S.; Ng, S.S.M.; Ma, B.B.Y.; Leung, T.Y.; Chan, S.L.; et al. Orientation-aware plasma cell-free DNA fragmentation analysis in open chromatin regions informs tissue of origin. Genome Res. 2019, 29, 418-427. [CrossRef]

72. Ulz, P.; Perakis, S.; Zhou, Q.; Moser, T.; Belic, J.; Lazzeri, I.; Wolfler, A.; Zebisch, A.; Gerger, A.; Pristauz, G.; et al. Inference of transcription factor binding from cell-free DNA enables tumor subtype prediction and early detection. Nat. Commun. 2019, 10, 4666. [CrossRef]

73. Lam, W.K.J.; Gai, W.; Sun, K.; Wong, R.S.M.; Chan, R.W.Y.; Jiang, P.; Chan, N.P.H.; Hui, W.W.I.; Chan, A.W.H.; Szeto, C.C.; et al. DNA of Erythroid Origin Is Present in Human Plasma and Informs the Types of Anemia. Clin. Chem. 2017, 63, 1614-1623. [CrossRef] [PubMed]

74. Vad-Nielsen, J.; Meldgaard, P.; Sorensen, B.S.; Nielsen, A.L. Cell-free Chromatin Immunoprecipitation (cfChIP) from blood plasma can determine gene-expression in tumors from non-small-cell lung cancer patients. Lung Cancer 2020, 147, 244-251. [CrossRef]

75. Cancer Genome Atlas Research Network. Comprehensive molecular profiling of lung adenocarcinoma. Nature 2014, 511, 543-550. [CrossRef] 
76. Bhattacharyya, S.; Pradhan, K.; Campbell, N.; Mazdo, J.; Vasantkumar, A.; Maqbool, S.; Bhagat, T.D.; Gupta, S.; Suzuki, M.; Yu, Y.; et al. Altered hydroxymethylation is seen at regulatory regions in pancreatic cancer and regulates oncogenic pathways. Genome Res. 2017, 27, 1830-1842. [CrossRef]

77. Saghafinia, S.; Mina, M.; Riggi, N.; Hanahan, D.; Ciriello, G. Pan-Cancer Landscape of Aberrant DNA Methylation across Human Tumors. Cell Rep. 2018, 25, 1066-1080. [CrossRef]

78. Li, M.; Gao, F.; Xia, Y.; Tang, Y.; Zhao, W.; Jin, C.; Luo, H.; Wang, J.; Li, Q.; Wang, Y. Filtrating colorectal cancer associated genes by integrated analyses of global DNA methylation and hydroxymethylation in cancer and normal tissue. Sci. Rep. 2016, 6, 31826. [CrossRef]

79. Dor, Y.; Cedar, H. Principles of DNA methylation and their implications for biology and medicine. Lancet 2018, 392, 777-786. [CrossRef]

80. Vogelstein, B.; Papadopoulos, N.; Velculescu, V.E.; Zhou, S.; Diaz, L.A., Jr.; Kinzler, K.W. Cancer genome landscapes. Science 2013, 339, 1546-1558. [CrossRef]

81. Guo, S.; Diep, D.; Plongthongkum, N.; Fung, H.L.; Zhang, K.; Zhang, K. Identification of methylation haplotype blocks aids in deconvolution of heterogeneous tissue samples and tumor tissue-of-origin mapping from plasma DNA. Nat. Genet. 2017, 49, 635-642. [CrossRef]

82. Liu, J.; Zhao, H.; Huang, Y.; Xu, S.; Zhou, Y.; Zhang, W.; Li, J.; Ming, Y.; Wang, X.; Zhao, S.; et al. Genome-wide cell-free DNA methylation analyses improve accuracy of non-invasive diagnostic imaging for early-stage breast cancer. Mol. Cancer 2021, 20, 36. [CrossRef] [PubMed]

83. Liu, M.C.; Oxnard, G.R.; Klein, E.A.; Swanton, C.; Seiden, M.V. Sensitive and specific multi-cancer detection and localization using methylation signatures in cell-free DNA. Ann. Oncol. 2020, 31, 745-759. [CrossRef]

84. Moss, J.; Zick, A.; Grinshpun, A.; Carmon, E.; Maoz, M.; Ochana, B.L.; Abraham, O.; Arieli, O.; Germansky, L.; Meir, K.; et al. Circulating breast-derived DNA allows universal detection and monitoring of localized breast cancer. Ann. Oncol. 2020, 31, 395-403. [CrossRef]

85. Nassiri, F.; Chakravarthy, A.; Feng, S.; Shen, S.Y.; Nejad, R.; Zuccato, J.A.; Voisin, M.R.; Patil, V.; Horbinski, C.; Aldape, K.; et al. Detection and discrimination of intracranial tumors using plasma cell-free DNA methylomes. Nat. Med. 2020, 26, $1044-1047$. [CrossRef]

86. Nuzzo, P.V.; Berchuck, J.E.; Korthauer, K.; Spisak, S.; Nassar, A.H.; Abou Alaiwi, S.; Chakravarthy, A.; Shen, S.Y.; Bakouny, Z.; Boccardo, F.; et al. Detection of renal cell carcinoma using plasma and urine cell-free DNA methylomes. Nat. Med. 2020, 26, 1041-1043. [CrossRef]

87. Shen, S.Y.; Singhania, R.; Fehringer, G.; Chakravarthy, A.; Roehrl, M.H.A.; Chadwick, D.; Zuzarte, P.C.; Borgida, A.; Wang, T.T.; Li, T.; et al. Sensitive tumour detection and classification using plasma cell-free DNA methylomes. Nature 2018, 563, 579-583. [CrossRef]

88. Chen, X.; Gole, J.; Gore, A.; He, Q.; Lu, M.; Min, J.; Yuan, Z.; Yang, X.; Jiang, Y.; Zhang, T.; et al. Non-invasive early detection of cancer four years before conventional diagnosis using a blood test. Nat. Commun. 2020, 11, 3475. [CrossRef]

89. Shen, S.Y.; Burgener, J.M.; Bratman, S.V.; De Carvalho, D.D. Preparation of cfMeDIP-seq libraries for methylome profiling of plasma cell-free DNA. Nat. Protoc. 2019, 14, 2749-2780. [CrossRef]

90. Zill, O.A.; Banks, K.C.; Fairclough, S.R.; Mortimer, S.A.; Vowles, J.V.; Mokhtari, R.; Gandara, D.R.; Mack, P.C.; Odegaard, J.I.; Nagy, R.J.; et al. The Landscape of Actionable Genomic Alterations in Cell-Free Circulating Tumor DNA from 21,807 Advanced Cancer Patients. Clin. Cancer Res. 2018, 24, 3528-3538. [CrossRef]

91. Togneri, F.S.; Ward, D.G.; Foster, J.M.; Devall, A.J.; Wojtowicz, P.; Alyas, S.; Vasques, F.R.; Oumie, A.; James, N.D.; Cheng, K.K.; et al. Genomic complexity of urothelial bladder cancer revealed in urinary cfDNA. Eur. J. Hum. Genet. 2016, 24, 1167-1174. [CrossRef]

92. Xia, Y.; Huang, C.C.; Dittmar, R.; Du, M.; Wang, Y.; Liu, H.; Shenoy, N.; Wang, L.; Kohli, M. Copy number variations in urine cell free DNA as biomarkers in advanced prostate cancer. Oncotarget 2016, 7, 35818-35831. [CrossRef]

93. Lu, T.; Li, J. Clinical applications of urinary cell-free DNA in cancer: Current insights and promising future. Am. J. Cancer Res. 2017, 7, 2318-2332. [PubMed]

94. Andersson, E.; Steven, K.; Guldberg, P. Size-based enrichment of exfoliated tumor cells in urine increases the sensitivity for DNA-based detection of bladder cancer. PLoS ONE 2014, 9, e94023. [CrossRef]

95. Van den Helder, R.; Wever, B.M.M.; van Trommel, N.E.; van Splunter, A.P.; Mom, C.H.; Kasius, J.C.; Bleeker, M.C.G.; Steenbergen, R.D.M. Non-invasive detection of endometrial cancer by DNA methylation analysis in urine. Clin. Epigenet. 2020, $12,165$. [CrossRef]

96. Larsen, L.K.; Jakobsen, J.S.; Abdul-Al, A.; Guldberg, P. Noninvasive Detection of High Grade Prostate Cancer by DNA Methylation Analysis of Urine Cells Captured by Microfiltration. J. Urol. 2018, 200, 749-757. [CrossRef]

97. Bach, S.; Paulis, I.; Sluiter, N.R.; Tibbesma, M.; Martin, I.; van de Wiel, M.A.; Tuynman, J.B.; Bahce, I.; Kazemier, G.; Steenbergen, R.D.M. Detection of colorectal cancer in urine using DNA methylation analysis. Sci. Rep. 2021, 11, 2363. [CrossRef]

98. Cheng, T.H.T.; Jiang, P.; Teoh, J.Y.C.; Heung, M.M.S.; Tam, J.C.W.; Sun, X.; Lee, W.S.; Ni, M.; Chan, R.C.K.; Ng, C.F.; et al. Noninvasive Detection of Bladder Cancer by Shallow-Depth Genome-Wide Bisulfite Sequencing of Urinary Cell-Free DNA for Methylation and Copy Number Profiling. Clin. Chem. 2019, 65, 927-936. [CrossRef] 
99. Luo, H.; Zhao, Q.; Wei, W.; Zheng, L.; Yi, S.; Li, G.; Wang, W.; Sheng, H.; Pu, H.; Mo, H.; et al. Circulating tumor DNA methylation profiles enable early diagnosis, prognosis prediction, and screening for colorectal cancer. Sci. Transl. Med. 2020, 12, eaax7533. [CrossRef]

100. Liu, M.; Klein, E.; Hubbell, E.; Maddala, T.; Aravanis, A.; Beausang, J.; Filippova, D.; Gross, S.; Jamshidi, A.; Kurtzman, K. Plasma cell-free DNA (cfDNA) assays for early multi-cancer detection: The circulating cell-free genome atlas (CCGA) study. Ann. Oncol. 2018, 29, viii14. [CrossRef]

101. Oxnard, G.R.; Klein, E.A.; Seiden, M.; Hubbell, E.; Venn, O.; Jamshidi, A.; Zhang, N.; Beausang, J.F.; Gross, S.; Kurtzman, K.N. Simultaneous multi-cancer detection and tissue of origin (TOO) localization using targeted bisulfite sequencing of plasma cell-free DNA (cfDNA). Ann. Oncol. 2019, 30, v912. [CrossRef]

102. Klein, E.A.; Richards, D.; Cohn, A.; Tummala, M.; Lapham, R.; Cosgrove, D.; Chung, G.; Clement, J.; Gao, J.; Hunkapiller, N.; et al. Clinical validation of a targeted methylation-based multi-cancer early detection test using an independent validation set. Ann. Oncol. 2021, 32, 1167-1177. [CrossRef]

103. Nadauld, L.D.; McDonnell, C.H.; Beer, T.M.; Liu, M.C.; Klein, E.A.; Hudnut, A.; Whittington, R.A.; Taylor, B.; Oxnard, G.R.; Lipson, J.; et al. The PATHFINDER Study: Assessment of the Implementation of an Investigational Multi-Cancer Early Detection Test Into Clinical Practice. Cancers 2021, 13, 3501. [CrossRef]

104. U.S. National Library of the Medicine. The SUMMIT Study: A Cancer Screening Study. Available online: https://clinicaltrials. gov/ct2/show / NCT03934866 (accessed on 20 August 2021).

105. U.S. National Library of the Medicine. The STRIVE Study: Development of a Blood Test for Early Detection of Multiple Cancer Types. Available online: https:/ / clinicaltrials.gov/ct2/show / NCT03085888 (accessed on 20 August 2021).

106. Ito, S.; Shen, L.; Dai, Q.; Wu, S.C.; Collins, L.B.; Swenberg, J.A.; He, C.; Zhang, Y. Tet proteins can convert 5-methylcytosine to 5-formylcytosine and 5-carboxylcytosine. Science 2011, 333, 1300-1303. [CrossRef]

107. Tahiliani, M.; Koh, K.P.; Shen, Y.; Pastor, W.A.; Bandukwala, H.; Brudno, Y.; Agarwal, S.; Iyer, L.M.; Liu, D.R.; Aravind, L.; et al. Conversion of 5-methylcytosine to 5-hydroxymethylcytosine in mammalian DNA by MLL partner TET1. Science 2009, 324, 930-935. [CrossRef]

108. Zhang, L.; Lu, X.; Lu, J.; Liang, H.; Dai, Q.; Xu, G.L.; Luo, C.; Jiang, H.; He, C. Thymine DNA glycosylase specifically recognizes 5-carboxylcytosine-modified DNA. Nat. Chem. Biol. 2012, 8, 328-330. [CrossRef]

109. He, Y.F.; Li, B.Z.; Li, Z.; Liu, P.; Wang, Y.; Tang, Q.; Ding, J.; Jia, Y.; Chen, Z.; Li, L.; et al. Tet-mediated formation of 5carboxylcytosine and its excision by TDG in mammalian DNA. Science 2011, 333, 1303-1307. [CrossRef]

110. Brazauskas, P.; Kriaucionis, S. DNA modifications: Another stable base in DNA. Nat. Chem. 2014, 6, 1031-1033. [CrossRef] [PubMed]

111. Bachman, M.; Uribe-Lewis, S.; Yang, X.; Williams, M.; Murrell, A.; Balasubramanian, S. 5-Hydroxymethylcytosine is a predominantly stable DNA modification. Nat. Chem. 2014, 6, 1049-1055. [CrossRef]

112. Globisch, D.; Münzel, M.; Müller, M.; Michalakis, S.; Wagner, M.; Koch, S.; Brückl, T.; Biel, M.; Carell, T. Tissue distribution of 5-hydroxymethylcytosine and search for active demethylation intermediates. PLoS ONE 2010, 5, e15367. [CrossRef] [PubMed]

113. Jin, C.; Lu, Y.; Jelinek, J.; Liang, S.; Estecio, M.R.; Barton, M.C.; Issa, J.P. TET1 is a maintenance DNA demethylase that prevents methylation spreading in differentiated cells. Nucleic Acids Res. 2014, 42, 6956-6971. [CrossRef]

114. Jeong, M.; Sun, D.; Luo, M.; Huang, Y.; Challen, G.A.; Rodriguez, B.; Zhang, X.; Chavez, L.; Wang, H.; Hannah, R.; et al. Large conserved domains of low DNA methylation maintained by Dnmt3a. Nat. Genet. 2014, 46, 17-23. [CrossRef] [PubMed]

115. Manzo, M.; Wirz, J.; Ambrosi, C.; Villasenor, R.; Roschitzki, B.; Baubec, T. Isoform-specific localization of DNMT3A regulates DNA methylation fidelity at bivalent CpG islands. EMBO J. 2017, 36, 3421-3434. [CrossRef]

116. Mellen, M.; Ayata, P.; Dewell, S.; Kriaucionis, S.; Heintz, N. MeCP2 binds to 5hmC enriched within active genes and accessible chromatin in the nervous system. Cell 2012, 151, 1417-1430. [CrossRef]

117. Thomson, J.P.; Lempiainen, H.; Hackett, J.A.; Nestor, C.E.; Muller, A.; Bolognani, F.; Oakeley, E.J.; Schubeler, D.; Terranova, R.; Reinhardt, D.; et al. Non-genotoxic carcinogen exposure induces defined changes in the 5-hydroxymethylome. Genome Biol. 2012, 13, R93. [CrossRef]

118. Li, W.; Liu, M. Distribution of 5-Hydroxymethylcytosine in Different Human Tissues. J. Nucleic Acids 2011, $2011,870726$. [CrossRef] [PubMed]

119. Haffner, M.C.; Chaux, A.; Meeker, A.K.; Esopi, D.M.; Gerber, J.; Pellakuru, L.G.; Toubaji, A.; Argani, P.; Iacobuzio-Donahue, C.; Nelson, W.G.; et al. Global 5-hydroxymethylcytosine content is significantly reduced in tissue stem/progenitor cell compartments and in human cancers. Oncotarget 2011, 2, 627-637. [CrossRef] [PubMed]

120. Lian, C.G.; Xu, Y.; Ceol, C.; Wu, F.; Larson, A.; Dresser, K.; Xu, W.; Tan, L.; Hu, Y.; Zhan, Q.; et al. Loss of 5-hydroxymethylcytosine is an epigenetic hallmark of melanoma. Cell 2012, 150, 1135-1146. [CrossRef]

121. Yang, H.; Liu, Y.; Bai, F.; Zhang, J.Y.; Ma, S.H.; Liu, J.; Xu, Z.D.; Zhu, H.G.; Ling, Z.Q.; Ye, D.; et al. Tumor development is associated with decrease of TET gene expression and 5-methylcytosine hydroxylation. Oncogene 2013, 32, 663-669. [CrossRef]

122. Yang, H.; Ye, D.; Guan, K.L.; Xiong, Y. IDH1 and IDH2 mutations in tumorigenesis: Mechanistic insights and clinical perspectives. Clin Cancer Res. 2012, 18, 5562-5571. [CrossRef] [PubMed]

123. Song, C.X.; Szulwach, K.E.; Fu, Y.; Dai, Q.; Yi, C.; Li, X.; Li, Y.; Chen, C.H.; Zhang, W.; Jian, X.; et al. Selective chemical labeling reveals the genome-wide distribution of 5-hydroxymethylcytosine. Nat. Biotechnol. 2011, 29, 68-72. [CrossRef] 
124. Bergamaschi, A.; Ning, Y.; Ku, C.-J.; Ellison, C.; Collin, F.; Guler, G.; Phillips, T.; McCarthy, E.; Wang, W.; Antoine, M.; et al. Pilot study demonstrating changes in DNA hydroxymethylation enable detection of multiple cancers in plasma cell-free DNA. medRxiv 2020. [CrossRef]

125. Cai, J.; Chen, L.; Zhang, Z.; Zhang, X.; Lu, X.; Liu, W.; Shi, G.; Ge, Y.; Gao, P.; Yang, Y.; et al. Genome-wide mapping of 5hydroxymethylcytosines in circulating cell-free DNA as a non-invasive approach for early detection of hepatocellular carcinoma. Gut 2019, 68, 2195-2205. [CrossRef]

126. Cai, Z.; Zhang, J.; He, Y.; Xia, L.; Dong, X.; Chen, G.; Zhou, Y.; Hu, X.; Zhong, S.; Wang, Y.; et al. Liquid biopsy by combining 5hydroxymethylcytosine signatures of plasma cell-free DNA and protein biomarkers for diagnosis and prognosis of hepatocellular carcinoma. ESMO Open 2021, 6, 100021. [CrossRef]

127. Cao, F.; Wei, A.; Hu, X.; He, Y.; Zhang, J.; Xia, L.; Tu, K.; Yuan, J.; Guo, Z.; Liu, H.; et al. Integrated epigenetic biomarkers in circulating cell-free DNA as a robust classifier for pancreatic cancer. Clin. Epigenet. 2020, 12, 112. [CrossRef]

128. Chiu, B.C.; Zhang, Z.; You, Q.; Zeng, C.; Stepniak, E.; Bracci, P.M.; Yu, K.; Venkataraman, G.; Smith, S.M.; He, C.; et al. Prognostic implications of 5-hydroxymethylcytosines from circulating cell-free DNA in diffuse large B-cell lymphoma. Blood Adv. 2019, 3, 2790-2799. [CrossRef]

129. Guler, G.D.; Ning, Y.; Ku, C.J.; Phillips, T.; McCarthy, E.; Ellison, C.K.; Bergamaschi, A.; Collin, F.; Lloyd, P.; Scott, A.; et al. Detection of early stage pancreatic cancer using 5-hydroxymethylcytosine signatures in circulating cell free DNA. Nat. Commun. 2020, 11, 5270. [CrossRef]

130. Song, C.X.; Yin, S.; Ma, L.; Wheeler, A.; Chen, Y.; Zhang, Y.; Liu, B.; Xiong, J.; Zhang, W.; Hu, J.; et al. 5-Hydroxymethylcytosine signatures in cell-free DNA provide information about tumor types and stages. Cell Res. 2017, 27, 1231-1242. [CrossRef]

131. Tian, X.; Sun, B.; Chen, C.; Gao, C.; Zhang, J.; Lu, X.; Wang, L.; Li, X.; Xing, Y.; Liu, R.; et al. Circulating tumor DNA 5-hydroxymethylcytosine as a novel diagnostic biomarker for esophageal cancer. Cell Res. 2018, 28, 597-600. [CrossRef] [PubMed]

132. Zhang, J.; Han, X.; Gao, C.; Xing, Y.; Qi, Z.; Liu, R.; Wang, Y.; Zhang, X.; Yang, Y.G.; Li, X.; et al. 5-Hydroxymethylome in Circulating Cell-free DNA as A Potential Biomarker for Non-small-cell Lung Cancer. Genom. Proteom. Bioinform. 2018, 16, 187-199. [CrossRef]

133. Pedersen, S.K.; Baker, R.T.; McEvoy, A.; Murray, D.H.; Thomas, M.; Molloy, P.L.; Mitchell, S.; Lockett, T.; Young, G.P.; LaPointe, L.C. A two-gene blood test for methylated DNA sensitive for colorectal cancer. PLoS ONE 2015, 10, e0125041. [CrossRef]

134. Peneder, P.; Stutz, A.M.; Surdez, D.; Krumbholz, M.; Semper, S.; Chicard, M.; Sheffield, N.C.; Pierron, G.; Lapouble, E.; Totzl, M.; et al. Multimodal analysis of cell-free DNA whole-genome sequencing for pediatric cancers with low mutational burden. Nat. Commun. 2021, 12, 3230. [CrossRef]

135. De Rubis, G.; Rajeev Krishnan, S.; Bebawy, M. Liquid Biopsies in Cancer Diagnosis, Monitoring, and Prognosis. Trends Pharmacol. Sci. 2019, 40, 172-186. [CrossRef] [PubMed]

136. Locke, W.J.; Guanzon, D.; Ma, C.; Liew, Y.J.; Duesing, K.R.; Fung, K.Y.C.; Ross, J.P. DNA Methylation Cancer Biomarkers: Translation to the Clinic. Front. Genet. 2019, 10, 1150. [CrossRef]

137. Scher, H.I.; Graf, R.P.; Schreiber, N.A.; McLaughlin, B.; Jendrisak, A.; Wang, Y.; Lee, J.; Greene, S.; Krupa, R.; Lu, D.; et al. Phenotypic Heterogeneity of Circulating Tumor Cells Informs Clinical Decisions between AR Signaling Inhibitors and Taxanes in Metastatic Prostate Cancer. Cancer Res. 2017, 77, 5687-5698. [CrossRef]

138. Dianat-Moghadam, H.; Azizi, M.; Eslami, S.Z.; Cortes-Hernandez, L.E.; Heidarifard, M.; Nouri, M.; Alix-Panabieres, C. The Role of Circulating Tumor Cells in the Metastatic Cascade: Biology, Technical Challenges, and Clinical Relevance. Cancers 2020, $12,867$. [CrossRef] [PubMed]

139. Yan, W.T.; Cui, X.; Chen, Q.; Li, Y.F.; Cui, Y.H.; Wang, Y.; Jiang, J. Circulating tumor cell status monitors the treatment responses in breast cancer patients: A meta-analysis. Sci. Rep. 2017, 7, 43464. [CrossRef] [PubMed]

140. Heller, G.; McCormack, R.; Kheoh, T.; Molina, A.; Smith, M.R.; Dreicer, R.; Saad, F.; de Wit, R.; Aftab, D.T.; Hirmand, M.; et al. Circulating Tumor Cell Number as a Response Measure of Prolonged Survival for Metastatic Castration-Resistant Prostate Cancer: A Comparison With Prostate-Specific Antigen Across Five Randomized Phase III Clinical Trials. J. Clin. Oncol. 2018, 36, 572-580. [CrossRef] [PubMed]

141. Alva, A.; Friedlander, T.; Clark, M.; Huebner, T.; Daignault, S.; Hussain, M.; Lee, C.; Hafez, K.; Hollenbeck, B.; Weizer, A.; et al. Circulating Tumor Cells as Potential Biomarkers in Bladder Cancer. J. Urol. 2015, 194, 790-798. [CrossRef] [PubMed] 